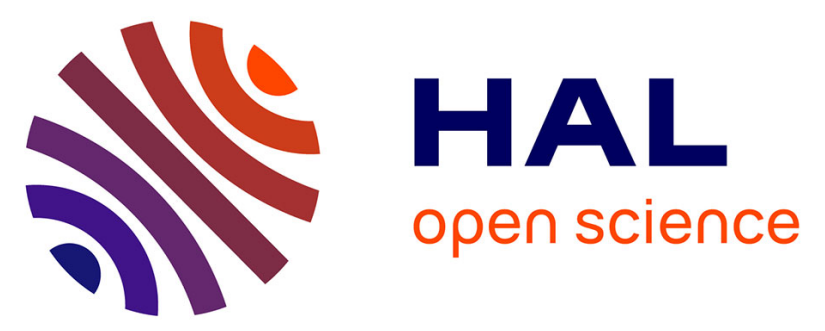

\title{
Plate interface rheological switches during subduction infancy: Control on slab penetration and metamorphic sole formation
}

Philippe Agard, Philippe Yamato, Mathieu Soret, Cécile Prigent, S. Guillot, Alexis Plunder, Benoît Dubacq, Alain Chauvet, Patrick Monie

\section{To cite this version:}

Philippe Agard, Philippe Yamato, Mathieu Soret, Cécile Prigent, S. Guillot, et al.. Plate interface rheological switches during subduction infancy: Control on slab penetration and metamorphic sole formation. Earth and Planetary Science Letters, 2016, 451, pp.208 - 220. 10.1016/j.epsl.2016.06.054 . hal-01383368

\section{HAL Id: hal-01383368 \\ https: / hal.sorbonne-universite.fr/hal-01383368}

Submitted on 18 Oct 2016

HAL is a multi-disciplinary open access archive for the deposit and dissemination of scientific research documents, whether they are published or not. The documents may come from teaching and research institutions in France or abroad, or from public or private research centers.
L'archive ouverte pluridisciplinaire HAL, est destinée au dépôt et à la diffusion de documents scientifiques de niveau recherche, publiés ou non, émanant des établissements d'enseignement et de recherche français ou étrangers, des laboratoires publics ou privés. 

control on slab penetration and metamorphic sole formation

$8 \quad{ }^{1}$ Sorbonne Universités, UPMC Univ Paris 06, CNRS, Institut des Sciences de la Terre de Paris

9 (iSTeP), 4 place Jussieu 75005 Paris, France

$10{ }^{2}$ Institut Universitaire de France, F-75005 Paris, France

$11{ }^{3}$ Géosciences Rennes, Université de Rennes 1, CNRS UMR 6118, F-35042 Rennes Cedex, France

$12{ }^{4}$ Univ. Grenoble Alpes, CNRS, ISTerre, F-38000 Grenoble, France

$13{ }^{5}$ Géosciences Montpellier, Univ Montpellier 2, CNRS, F-34095 Montpellier, France 


\section{Abstract}

24 Subduction infancy corresponds to the first few million years following subduction initiation, when slabs start their descent into the mantle. It coincides with the transient (yet systematic) transfer of material from the top of the slab to the upper plate, as witnessed by metamorphic soles welded beneath obducted ophiolites. Combining structure-lithology-pressure-temperature-time data from metamorphic soles with flow laws derived from experimental rock mechanics, this study highlights two main successive rheological switches across the subduction interface (mantle wedge vs. basalts, then mantle wedge vs. sediments; at $\sim 800^{\circ} \mathrm{C}$ and $\sim 600^{\circ} \mathrm{C}$, respectively), during which interplate mechanical coupling is maximized by the existence of transiently similar rheologies across the plate contact. We propose that these rheological switches hinder slab penetration and are responsible for slicing the top of the slab and welding crustal pieces (high- then low-temperature metamorphic soles) to the base of the mantle wedge during subduction infancy. This mechanism has implications for the rheological properties of the crust and mantle (and for transient episodes of accretion/exhumation of HP-LT rocks in mature subduction systems) and highlights the role of fluids in enabling subduction to overcome the early resistance to slab penetration.

Keywords:

41 Subduction, metamorphic sole, rheology, plate interface, slab dehydration, mechanical coupling 


\section{Introduction}

Understanding subduction initiation, in both space and time, has been a challenge since the advent of plate tectonics (Dewey, 1976; Regenauer-Lieb et al., 2001; Gurnis et al., 2004). What is referred to as "subduction initiation" in the literature encompasses two different concepts and periods: (i) how and where subduction nucleates (i.e., what triggers the beginning of subduction; e.g., Regenauer-Lieb et al., 2001; Stern, 2004), and (ii) how subduction proceeds over the first few million years of its history ("subduction infancy"; Stern and Bloomer, 1992).

This study focuses on subduction infancy, when a newly born slab starts its descent into the mantle and when the thermal regime of the subduction zone progressively cools down before reaching steady-state (e.g., Syracuse et al., 2010; Plunder et al., 2015; Figs. 1a,b). The only rock remnants of this elusive geodynamic step are thin $(\sim 10-500 \mathrm{~m})$ metamorphosed slivers of oceanic crust (metamorphic soles; Williams and Smyth, 1973; Wakabayashi and Dilek, 2000) found beneath pristine, 100-1000 km long, $\leq 10-15 \mathrm{~km}$ thick fragments of oceanic lithosphere emplaced on top of continents as ophiolites (Coleman, 1981; Nicolas, 1989; Fig. 1c).

Metamorphic soles correspond to upper crustal material from the downgoing slab (with variable proportions of basalts and pelagic sediments; Spray et al. 1984; Boudier et al., 1988) and have long been recognized as formed during the first few My of intra-oceanic subduction (Fig. 1b; Dewey, 1976; Spray et al., 1984; Dewey and Casey, 2013). Their formation would result from heat transfer from the upper plate mantle and/or shear heating when the slab enters the mantle and heats up

71 (Dewey, 1976; Hacker, 1990). Explaining how such thin metamorphosed tectonic slivers of oceanic crust get welded ("underplated") to the upper plate along hundreds of km (e.g., Oman, Turkey: 
during subduction infancy (and possibly during later subduction), but has so far remained enigmatic (Jamieson, 1981; Dewey and Casey, 2013).

This problem is herein addressed by (i) compiling worldwide characteristics of metamorphic soles (i.e., lithologies, internal organization, thicknesses, thermobarometric constraints), augmented by refined estimates for their pressure-temperature (P-T) conditions of formation using thermodynamic modelling and by (ii) calculating effective viscosities of materials present along the plate interface from known rheological properties for the crust and mantle (i.e., peridotite, basalt, sediment, serpentinite).

This study reveals the existence of rheological switches across the subduction interface, and proposes that these changes in rheological properties control slab penetration into the mantle and the formation of metamorphic soles during subduction infancy. This mechanism has implications for effective rheologies of the crust and mantle and for the general understanding of accretion processes and early slab dynamics.

\section{Metamorphic soles: the record of subduction infancy}

\subsection{Metamorphic sole constitution}

The main characteristics (i.e., structural position, lithologies, constitution) and P-T conditions of metamorphic soles worldwide are reviewed in figure 2 and Table 1 . This synthesis shows that metamorphic soles are ubiquitous beneath non-metamorphosed ophiolites (e.g., Oman, Turkey, Papua, Newfoundland) and share similar characteristics regardless of the ophiolite or the detailed geological/geodynamical setting (Spray, 1984; Wakabayashi and Dilek, 2003). Radiometric ages of metamorphic soles and ophiolites generally fall within 1-2 My (e.g., Fig. 1d for Oman; Hacker et al., 1996; Rioux et al., 2013), suggesting the existence of a still warm (i.e., > $1000^{\circ} \mathrm{C}$ ) upper plate mantle near the subduction interface.

Metamorphic soles comprise $\sim 10$ to $\sim 500 \mathrm{~m}$ thick (Figs. 2b-c) highly strained and metamorphosed crustal rocks where amphibolitized metabasalt dominates, together with increasing 
proportions of pelagic metasediment structurally downwards (mainly metaradiolarite, with 102 intercalations of metatuff and metapelite downwards). Vertically, metamorphic soles exhibit an 103 inverted metamorphic sequence with isograds subparallel to the basal peridotite foliation (Spray, 104 1984). They grade steeply from thin high temperature (HT) granulite/amphibolite facies lithologies 105 adjacent to the overlying peridotites $\left(>700-850^{\circ}\right.$ C; Fig. 2 d; e.g., McCaig, 1983 ; Jamieson, 1986) to 106 thicker amphibolite/greenschist facies low temperature soles (LT; $\sim 550-650^{\circ} \mathrm{C}$; Table 1). This 107 temperature trend is not continuous, however, since the structurally and thermally lower LT sole is 108 arguably formed later, and at lower pressure than the HT sole, by successive stacking of increasing 109 amounts of metasediment (e.g., Malpas, 1979; Casey and Dewey, 1984; Jamieson, 1986; Fig. 2d). 110 Whenever radiometric constraints are available, HT soles are coeval or slightly older than LT soles, 111 yet within 2 My (e.g., for Oman: Fig. 1d; Hacker et al., 1996; Roberts et al., 2016). HT soles 112 and/or LT soles may be missing in places but wherever both are observed, and not disturbed by 113 obvious later tectonics, HT soles are overlying LT soles.

114 High deformation in the HT and LT soles is marked by mylonites and complex recumbent 115 folding. This deformation, however, is commonly less conspicuous in HT sole mafic amphibolites 116 than in the LT soles (Jamieson, 1981; this study), due to the extent of recrystallization (e.g., Oman) 117 and/or to the lack of lithological heterogeneities. Wherever (rarely) preserved, stretching lineations 118 in the HT soles and LT soles strike differently (e.g., Newfoundland; Dewey and Casey, 2013), 119 suggesting that boundary conditions and/or accretion dynamics may have been modified during 120 sequential underplating.

121 Some earlier workers, on the basis of rare gabbroic occurrences (associated with dunite and 122 locally intercalated between the mantle and the HT metamorphic amphibolite; Jamieson, 1981), 123 suggested that the whole metamorphic sole could represent a metamorphosed, overturned limb of 124 ophiolite crust (with sediments, basalts and gabbros from bottom to top; see also Wakabayashi and 125 Dilek, 2003). This interpretation is however unlikely: (i) in contrast with the ophiolite crust, 126 gabbros are extremely rare in the soles (and may represent small-scale intrusions in the mantle), (ii) 127 HT mafic amphibolites tend to have a distinctive nature/geochemical signature (i.e., MORB 
transitional to OIB or E-MORB; Dewey and Casey, 2013) and (iii) the overturned limb hypothesis

129 fails to explain why pressure conditions in the metasedimentary LT sole are lower than in the HT 130 sole located above (Gnos, 1998; section 2.2).

The mantle rocks immediately above the metamorphic sole are also highly deformed (Fig. 2d), showing m- to hm-scale deformation patterns consistent with those observed in the underlying HT sole (Boudier et al., 1988), pressure estimates equivalent to those of HT sole peak metamorphism (Jamieson, 1981; McCaig, 1983) and porphyroclastic to ultramylonitic textures formed in the temperature range of $1100^{\circ} \mathrm{C}$ down to $\sim 700^{\circ} \mathrm{C}$ (Boudier et al., 1988; Michibayashi and Mainprice, 2004; Linckens et al., 2011b). This suggests that the base of the ophiolite mantle deformed and cooled during subduction infancy and that, from a mechanical point of view, the metamorphic sole should be considered as a threefold stack with, from bottom to top, the LT sole, the HT sole and the base of the ophiolitic mantle sequence (hereafter noted as: LTsolelHTsolelbasal peridotites).

\subsection{P-T conditions of metamorphic soles}

Published P-T estimates for metamorphic sole formation (Fig. 3a; Table 1) spread along a high

to medium T/P gradient, which partly arises from the diversity and variable precision of

thermobarometric methods used. New P-T estimates for HT soles are provided here using thermodynamic modelling. P-T phase diagrams for fixed bulk rock composition (pseudosections) were calculated to constrain the conditions of HT sole formation using the Gibbs-free-energy minimization software THERIAK/DOMINO (de Capitani and Petrakakis, 2010; with the updated database of Holland and Powell (1998); tcdb55cc2d.bs) with the following solution models: Diener et al. (2007) for amphibole, Green et al. (2007) for clinopyroxene, White et al. (2007) for orthopyroxene, Holland et al. (1998) for chlorite, Baldwin et al. (2005) for plagioclase and Holland and Powell (1998) for garnet. P-T conditions for LT soles are difficult to assess, unfortunately, owing to the high variance of the assemblages and uncertainties in thermodynamic models. 
ophiolite, W. Turkey) with garnet, clinopyroxene, plagioclase and amphibole. The corresponding sample comes from the region of Salda (South Western Turkey; N03746'44" E02956'21"), where garnet-clinopyroxene amphibolites are passing downwards, away from the contact with the overlying peridotite, to amphibolites and then to greenschist facies rocks. Spinel is replaced by plagioclase in the nearby peridotite, suggesting former equilibration of the rock at pressures $>0.8-1$ GPa. At the thin section scale, garnet and clinopyroxene are intimately intergrown (with globular shape inclusions of clinopyroxene in garnet). Amphibole and plagioclase are found both in the matrix and as inclusions in garnet and clinopyroxene, and therefore formed during peak conditions. Clinopyroxene has diopside compositions with $\mathrm{Mg \#} \sim 0.80$ and a Ca content of $0.88-$ 0.91 per formula unit (p.f.u.). The pyrope content in garnet ranges between $0.20-0.28$ p.f.u. and plagioclase (when preserved) has an anorthite fraction of 0.2-0.3.

P-T conditions for the garnet-clinopyroxene-amphibole-plagioclase peak assemblage of sample YE1302b, using mineral isopleths, are $1.08 \pm 0.1 \mathrm{GPa}$ and $780 \pm 40{ }^{\circ} \mathrm{C}$. Water amounts were set to match amphibole modes (50-60 vol\%). $\mathrm{TiO}_{2}$ was neglected in the calculation as it enters mainly accessory minerals (rutile, titanite) and amphibole, in which titanium is not accounted for (Diener et al., 2007). The $\mathrm{MnO}$ content reproduces the observed garnet chemistry and ensures consistent garnet and clinopyroxene Fe-Mg exchange.

A similar range of estimates was obtained with phase diagrams for metamorphic soles from Turkey (in Kütahya; boxes in Fig. 3a; Table 1) and Oman (in Sumeini and Khubakhib; dashed boxes, Fig. 3a), pointing to definitely high P values for the upper HT soles when compared to the spread of published estimates (i.e., black dots in Fig. 3a). This conclusion is strengthened by the similarity of available mineral assemblages and compositions worldwide. These estimates are consistent with the presence of only subordinate amounts of melts in the HT soles (Gnos, 1998), suggesting that temperatures do not significantly exceed amphibolite dehydration melting (in agreement with predicted melt fractions $<5-10$ vol\% at $850^{\circ} \mathrm{C}$, depending on pressure; Green et al., 2016). 


\subsection{Significance of metamorphic soles within thermal subduction regimes}

The above compilation shows that conditions for metamorphic sole formation are remarkably

similar worldwide and characterized by the accretion of HT soles that are thinner, more mafic, accreted earlier, at greater depths, at almost invariant P-T conditions $\left(800 \pm 50^{\circ} \mathrm{C}\right.$ at $\left.1.0 \pm 0.2 \mathrm{GPa}\right)$ and always on top of LT soles (equilibrated at $\sim 600 \pm 50^{\circ} \mathrm{C}$ at $0.5 \pm 0.1 \mathrm{GPa}$ ).

These estimates are compared to peak conditions reached by oceanic rocks during later subduction, namely those for HT and LT eclogites (Fig. 3a; see Agard et al., 2009 for a review). Their contrasting P-T conditions exemplify the change in the subduction thermal gradient through time, from warm to cold, from peak burial conditions of $\sim 800^{\circ} \mathrm{C}$ and $1.0 \mathrm{GPa}$ to $\sim 550^{\circ} \mathrm{C}$ and 2.5 GPa. Figure 3a shows that during subduction infancy and subsequent cooling, three rock types successively form from the upper crust of the down-going slab: (1) metamorphic soles within the first 1-2 My, along the hotter gradient, (2) HT oceanic eclogites postdating initiation by 5 My, commonly exhumed in serpentinite mélanges with counter-clockwise P-T paths (arrows in Fig. 3a; e.g., Wakabayashi, 1990; Garcia-Casco et al., 2006), (3) LT oceanic eclogites formed after 5-10 My and, whenever exhumed, mostly as continuous tectonic slices.

Contrary to metamorphic soles, the fraction of eclogites exhumed worldwide is only rarely accreted to an upper plate ophiolite mantle. Figure 3 a also shows that accretion largely overlaps the domain where serpentine is not stable.

Most HT metamorphic soles do not show later HP-LT metamorphism overprint, such as would implication is that the HT soles formed at $\sim 1 \mathrm{GPa}$ must have been accreted and partly exhumed (together with the deformed base of the ophiolite mantle) during subduction infancy (i.e., before significant cooling of the subduction thermal regime), and later underplated below the undeformed ophiolite mantle. 
A generic mechanical process is needed to explain how slices of crustal material from the slab get accreted to the mantle wedge (i) only during subduction infancy and (ii) in such a uniform manner. Accretion (or "underplating") of any tectonic slice across the subduction interface requires the combination of:

(i) an increase in mechanical coupling across the plate contact beyond some threshold, in order to preferentially localize strain and relative displacement elsewhere within the slab, along some other physical discontinuity (e.g., basalt vs. sediment, or basalt vs. sheeted dykes; Kimura and Ludden, 1995; Dewey and Casey, 2013),

(ii) some deformation mechanisms allowing for effective slicing within the slab. Whether slicing takes place through slow creep, fluid-mediated slip (such as slow slip events) or repeated regular earthquakes is unknown to date and beyond the scope of the present study.

Noteworthily, mechanical coupling is maximum when rheologies on both sides of the plate interface are similar: strain is otherwise localized and the interface is decoupled.

effective viscosity $(\eta)$ of plate interface materials as a function of temperature (T). Figure 4a shows

this dependency for rocks expected to lie at the base of the upper plate (peridotite, serpentinite) and at the top of the slab (basalt, sediment), using a strain rate $\left({ }^{\circ}\right)$ derived from natural constraints $\left(10^{-}\right.$ ${ }^{13} \mathrm{~s}^{-1}$ for Oman; Linckens et al., 2011b) and the following formula:

\subsection{Effective viscosities of plate interface material constrained by rock mechanics}

Flow laws derived from experimental rock mechanics (Table 2) are used to estimate the

where $n, A, Q$ and $R$ correspond to the power-law exponent, the material constant, the activation energy and the gas constant, respectively.

$$
\eta=\frac{1}{2} A^{-\frac{1}{n}} \cdot \dot{\varepsilon}^{\frac{1-n}{n}} \exp \left(\frac{Q}{n R T}\right)
$$

The reader is referred to Karato (2010) and Hirth and Kohldstedt (2015) for reviews of flow laws of relevance for the mantle. These were derived from experiments on dry or wet olivine for 
dislocation creep (e.g., Hirth and Kohlstedt, 2003) and for grain size dependent deformation mechanisms such as diffusion creep (Hirth and Kholstedt, 2003; Faul and Jackson, 2007) and dislocation-accommodated grain boundary sliding (disGBS; Hirth and Kohldstedt, 2003: Hansen et al., 2011). Important independent constraints on mantle deformation along the plate interface come from natural data on basal peridotites and mantle shear zones rooting in the deformed mantle base of the ophiolite (Boudier et al., 1988; Linckens et al., 2011a,b). The evolution from $1100^{\circ} \mathrm{C}$ in porphyroclastic peridotites to $\sim 700^{\circ} \mathrm{C}$ in ultramylonites shows that (i) olivine grain size decreases from $\sim 2 \mathrm{~mm}$ to $10-50 \mu \mathrm{m}$ and (ii) deformation mechanisms evolve at $\sim 800-850^{\circ} \mathrm{C}$ from dislocation creep to grain size sensitive creep, diffusion creep being the most likely dominant mechanism in localized shear bands (the boundary between diffusion creep and disGBS is not well known however; Linckens et al., 2011b).

Flow laws for metamorphic sole mafic rocks are scarce in comparison and can be approached by using wet/dry diabase and mafic granulite. Flow laws are even scarcer for metasediments (Table 2). Given the abundance of metaradiolarites in the LT soles, the flow law of quartz is considered here as representative. Felsic granulite (dashed purple curve; Fig. 4a) may represent an equivalent to a strongly metamorphosed metasediment.

Importantly, at any given temperature and (at least as a first order approximation) regardless of which flow law is used, the mechanical strength of peridotite (i.e., dry or wet olivine: thick green curves and green overlay, respectively; Fig. 4a) is greater than that of mafic oceanic crust (blue overlay in Fig. 4b). Sediments are weaker than basalt, yet stronger than serpentinite. This is emphasized in figure $4 \mathrm{~b}$, where averages of flow laws are shown for the mantle (i.e., dislocation creep for dry and wet olivine and diffusion creep or disGBS with a grain size of $30 \mu \mathrm{m}$ ), for the mafic crust ("basalt") and for serpentinite. It is emphasized that changing the strain rate modifies the absolute value of $\eta$ but does not affect the relative position of these curves (see supplementary 260 figure S1). The strength contrasts existing between these different materials therefore seem 261 independent of strain rate. 
Slab dehydration (see Faccenda, 2014 for a review) can be anticipated to be critical for mechanical coupling during subduction infancy. Fluids released into the nascent mantle wedge (Fig. 2664 c) will induce serpentinization of the mantle below $\sim 550-650^{\circ} \mathrm{C}$ (depending on pressure: Fig. 3a; 267 Ulmer and Trommsdorff, 1995). These fluids will be stored in progressively lesser amounts deeper down, first as hydrous phases such as chlorite \pm amphibole \pm phlogopite \pm talc, then at $\mathrm{T}>\sim 850$ $900^{\circ} \mathrm{C}$ as fluid inclusions or point defects in nominally anhydrous minerals such as olivine or pyroxene (Hirth and Kohlstedt, 2015).

Contrary to the general increase of material strength with cooling (Fig. 4b), cooling of hydrated mantle wedge peridotites will therefore progressively weaken the mantle wedge towards serpentinite rheology (from point i to f; Fig. 4b) by (i) absorption of $\mathrm{OH}$ in olivine ("wet" olivine) at $1000-900^{\circ} \mathrm{C}$ and changes in deformation mechanisms from dislocation creep to grain size sensitive creep at $\mathrm{T}<\sim 850-900^{\circ} \mathrm{C}$ (i.e., diffusion creep and disGBS), (ii) formation of weaker hydrated minerals and eventually (iii) serpentinization. Noteworthily, the viscosity of an even mildly serpentinised peridotite (> 15\%) approaches that of pure serpentine (Escartin et al., 2001).

Although the exact rheological path from peridotite to serpentinite cannot be precisely quantified presently, an important conclusion is that mantle wedge viscosities will cross over the curves for metabasalt and then metasediment (Fig. 4b): these two "rheological switches" (i.e., when the mantle wedge first becomes weaker than basalts, then than sediments) most probably occur at $\mathrm{T}$ $\sim 800^{\circ} \mathrm{C}$ (where deformation by diffusion creep and disGBS have similar effective viscosities; Figs. 4a,b) and $\sim 600^{\circ} \mathrm{C}$, respectively. The temperature and viscosity values for the HT rheological switch (Fig. 4d) both match the temperature (T 800-850 ${ }^{\circ} \mathrm{C}$; Boudier et al., 1988; Linckens et al., 2011a) and viscosity ( $\eta \sim 10^{20-21}$ Pa.s; Linckens et al., 2011b; Tasaka et al., 2014) inferred from the high strain mylonitic to ultramylonitic deformation of adjacent banded peridotites from the base of the ophiolite. 


\subsection{Evolution of rheological contrasts across the plate interface during subduction infancy}

Figure $4 \mathrm{~d}$ shows the evolution of the rheological contrast across the plate interface during incipient slab penetration, as the top of the slab progressively heats up, weakens and dehydrates. The top of the slab is first considered as essentially made of mafic crust (i.e., basalt; Fig. 4c), sediments being probably scarce at the start of intra-oceanic subduction, far away from the continent (Fig. 1a). At shallow depths and for temperatures below $\sim 550-600^{\circ} \mathrm{C}$, the subducting oceanic (basaltic) crust is juxtaposed against an incipiently serpentinised mantle on top (as schematized in Fig. 4c). A sharp viscosity contrast $(\Delta \eta)$ exists on either side of the subduction plane 300 (strong basalt vs. weak mantle wedge; Fig. 4d).

As depth and temperature increase, the subducting crust weakens and progressively encounters a warmer, stronger, unserpentinised and less hydrated mantle wedge $\left(\Delta \eta^{\prime}\right.$ on Fig. $\left.4 d\right)$, where grain size sensitive deformation mechanisms take over (Linckens et al., 2011a; Hirth and Kohldstedt, 2015). The viscosity contrast across the interface reverses (weak basalt vs. stronger mantle wedge) at $\mathrm{T}>\sim 800^{\circ} \mathrm{C}$, once the subducting crust is juxtaposed against an almost dry peridotite rheology $(\Delta \eta "$ on Fig. $4 d)$. switch"; Fig. 4d). Although the extent to which basalts and sediments harden as a result of prograde mineral transformations is unknown, flow laws indicate that these rheological switches exist, even

311 considering the change from basalt to mafic granulite or from sediment/quartzite to felsic granulite (Fig. 4a). They will also take place regardless of the age of the overriding lithosphere, although at different depths (the warmer the lithosphere, the shallower the rheological switches). penetration: 
(i) at any given time the strength of the mantle wedge will increase downwards (Fig. 4c), so that the slab can be expected to face greater resistance to penetration with depth (at least until mantle melting occurs);

(ii) as the thermal regime cools with time, the domain where serpentine is stable ("serp. front" in Fig. 4c) will expand continuously downwards.

\subsection{Metamorphic sole formation linked to strong interplate mechanical coupling}

Effective viscosities of the lower plate crust and upper plate mantle therefore converge and switch, during subduction infancy, across restricted T windows (Fig. 4d; with P and time generally

$\sim 1 \mathrm{GPa}$ and $<2 \mathrm{Myr}$, these are restricted P-T-t windows too). We propose that the detachment and accretion of metamorphic soles is triggered by peaks of interplate mechanical coupling associated with rheological switches, that distribute deformation over large, km-scale bands across the subduction interface (e.g., Yuen et al., 1978) and localize strain further into the slab where/if a sharper viscosity contrast exists (e.g., Kimura and Ludden, 1995).

Slab penetration and metamorphic sole formation are tentatively reconstructed in figure 5 in three major steps (isotherms and depth-time trajectories are from thermo-kinematic models detailed in supplementary material; Figs. S2-4):

(1) Plate interface mechanical strength peaks during the first rheological switch (metamorphosed basalt vs. metasomatized upper mantle; Fig. 5a) at T $750-850^{\circ} \mathrm{C}$, leading to the formation of essentially mafic HT metamorphic soles (dot 1a, Fig. 4d). Detachment on a weaker horizon within the slab probably takes place at the transition between hydrothermalized/weakened basaltic layers and drier basalts below, and/or between basalts and sheeted dykes (if present), accounting for the general lack of metagabbros in metamorphic soles.

(2) Accretion of the metasedimentary-rich LT soles takes place at lower T (and P) conditions at $\sim 550-650^{\circ} \mathrm{C}$ and $\sim 0.5 \mathrm{GPa}$, after the partial exhumation of the HT sole (Fig. $5 \mathrm{~b}$ ). This corresponds can however be envisioned: (i) between the sediments and the incipiently serpentinised, weakening 
upper mantle (option 1; Fig. 5d) or (ii) between the sediments and the base of the HT sole (option 2;

344 Fig. 5d), whose viscosity will be shifted from basalt to sediment as the sedimentary column 345 increases (blue arrow, Fig. 4b; a similar shift is expected if strain rate increases or if basalt from the 346 HT sole get hydrated by water released from sediments below). Option 2 is supported by the 347 general lack of (serpentinised) mantle between the LT and HT sole (see section 2). Option 1 implies 348 that the mantle above the LT sole is tectonically removed by the exhumation of the (more resistant) 349 HT sole and basal peridotites (Fig. 5d). Option 1 would nevertheless explain the occurrence of LT 350 soles directly beneath the mantle. Accretion of the LT sole indicates, in any case, that the 351 detachment horizon within the slab is located within the sedimentary pile.

The fact that HT soles are thinner than LT soles could result from larger amounts of accumulated strain and later ductile thinning, from the peeling of thinner slices during the first rheological switch and/or from longer duration of accretion during the LT episode.

(3) As the thermal regime of the subduction continues to decrease (Fig. 5c), incoming sediment and basalt remain stronger than the increasingly serpentinised mantle wedge (Fig. 4d): the plate interface progressively 'unzips' downwards. LT eclogites, which start forming within the refrigerated subduction zone (Fig. 5c), are less likely to get mechanically coupled to the weakened upper plate. This can be the reason why they are rarely exhumed (Agard et al., 2009), in agreement

\subsection{Impact of subduction cooling on interplate mechanical coupling}

Figure 5 highlights how cooling dramatically impacts slab penetration during subduction infancy:

(i) The mantle wedge acts as a buttress which progressively softens with time: it only transiently peels off the slab crust during the first My, thereby forming metamorphic soles, then progressively loses strength with cooling/serpentinization until full decoupling;

(ii) Strain localizes with time in shallower decoupling horizons within the slab (Fig. 5e): accretion 
plate interface becomes decoupled after a few My (stage c), accretion is restricted to shallow, near-

371 trench infill (e.g., unmetamorphosed Hawasina units found in Oman beneath the metamorphic sole 372 and the ophiolite; Searle and Malpas, 1980; Searle and Cox, 2002), as in present-day accretionary 373 wedges (e.g., Nankai prism). The width of the plate interface shear zone may therefore decrease 374 with time.

The proposed mechanism for metamorphic sole formation and slab penetration (Fig. 5) explains why, through two main steps of accretion, metamorphic soles form and get accreted at remarkably similar P-T-time conditions worldwide (section 2.3) and across a transient period of subduction lifetime only (i.e., when rheological switches take place).

\subsection{Uncertainties on P-T-time conditions, viscosity estimates and strain rate}

\subsubsection{P-T-time constraints} amphiboles are complex and mafic melts are notoriously difficult to model (Diener and Powell, 2012 and references therein; Green et al., 2016). Larger uncertainties on pressure conditions for LT soles arise from lesser constraints in the high-variance greenschist to epidote amphibolite fields. The major uncertainty therefore lies in the exact pressure gap between the HT and LT soles, and whether there might be a continuum in between.

Age constraints for HT and LT metamorphic soles tightly cluster within 1-2 My (Table 1; Fig. 1d). The short duration of the process and/or apparent synchronicity might be exaggerated by the fact that ${ }^{40} \mathrm{Ar} /{ }^{39} \mathrm{Ar}$ ages on amphibole may represent cooling ages for the HT soles (i.e., below $550^{\circ} \mathrm{C}$ ), whereas age constraints for the LT sole could represent crystallization ages. But the fact 
that the LT soles are found below the HT ones (whom underlie the mantle base of the ophiolite) leaves little doubt that they were accreted afterwards. Thermo-mechanical modelling of a cooling subduction zone also shows that cooling lasts no more than a few My (Duretz et al., 2015).

\subsubsection{Viscosities and strain rates}

One of the largest uncertainties with experimental flow laws is that they are performed at (and extrapolated from) conditions orders of magnitude faster than nature (typically $10^{-4}-10^{-6} \mathrm{~s}^{-1}$ versus $10^{-12}-10^{-15} \mathrm{~s}^{-1}$ in nature; Burov, 2011; Hirth and Kohlstedt, 2015). Field evidence, however, suggests that mafic, clinopyroxene and plagioclase bearing lithologies are $\sim 2$ orders of magnitude weaker than dry peridotite at $\sim 700-800^{\circ} \mathrm{C}$ (e.g., Homburg et al., 2010), in agreement with the respective position of calculated flow laws (Fig. 4b,c). Viscosity estimates for the first, HT rheological switch $\left(\sim 10^{20-21}\right.$ Pa.s; Fig. 4d) are also in remarkable agreement with values deduced from natural observations on strained peridotites from the (ultra)mylonitic base of the ophiolite mantle $\left(10^{20-21}\right.$ Pa.s; Linckens et al., 2011b; Tasaka et al., 2014).

Another uncertainty comes from the simplifying assumption of considering similar strain rates for estimating the viscosities of all lithologies (Fig. 4b), whereas faster strain rates can be expected where strain localization takes place. Regardless of strain rate, however, "rheological switches" and converging mechanical behaviour between the mantle and basalt/sediment will take place across the interface: as the mantle wedge evolves progressively from dry to serpentinised, its viscosity curve is bound to cross that of basalt then of sediment (Fig. $4 \mathrm{~b}, \mathrm{~d}$ ), and this order is independent of strain rate (e.g., from $10^{12}$ to $10^{14} \mathrm{~s}^{-1}$; Fig. S1). This conclusion is not modified by shear heating either, which only changes the temperature field and shifts the $\mathrm{T}$ window of metamorphic sole formation to shallower depths, but not the characteristic "S-shape" of the isotherms (Fig. S5; so does the thermal state of the upper plate: Figs. S2b,c).

Complex feedbacks may nevertheless exist, since similar viscosities on each side will increase interplate mechanical coupling, which will in turn decrease strain rates, hence probably decrease 
of this scenario using self-consistent fully coupled thermomechanical models is therefore needed,

425 but there are major challenges:

(i) refined rheologies for sediments, variably hydrated basalts and gabbros, taking into account the influence of hydrothermal alteration, progressive metamorphic recrystallization, water loss or plagioclase content on crustal rocks are unknown (e.g., Getsinger and Hirth, 2014). The same holds true for the rheology of the mantle wedge (as yet unconstrained, as is fluid migration inside; Faccenda, 2014), for polyphase lithologies that also probably exist along the plate interface, for the impact of subordinate amounts of melt in the HT soles $(<\sim 10 \%)$, or for assessing the influence of pressure or the extent to which frictional energy is converted into heat (which also depends on rheological laws).

(ii) appropriate spatial resolution (i.e., down to $\sim 10 \mathrm{~m}$ ) is required in self-consistent viscoelasto-plastic geodynamic models in order to localize strain and (progressively) slice and detach pieces from the slab, in addition to reaching sufficient temporal resolution (e.g., van Dinther et al., 2014).

Further modelling will help constrain the depth and duration of these processes. The simple thermo-kinematic models used to derive the isotherms of figure 5 (see supplementary material) suggest that for a set of realistic velocities, initial thermal age and slab dip, incoming crustal rocks may cross the temperature range of HT sole formation $\left(\sim 750-850^{\circ} \mathrm{C}\right)$ at depths of $\sim 25-35 \mathrm{~km}$ and that accretion of individual slices may last on the order of 0.3-0.4 My (Fig. S3). Although inferred from simplified models, these constraints point to the possible formation of metamorphic soles 444 across a range of depths, possibly accounting for some of the scatter observed in the P-T estimates 445 for metamorphic soles worldwide (Fig. 3a).

\subsection{Accretion and exhumation during subduction infancy}

\subsubsection{Accretion of HT soles and incorporation of HT eclogites in serpentinite mélanges}

Accretion of mafic HT soles will last less than shown in the reconstruction and probably stop 
the plate interface (Fig. 5b): since incoming sediments reach their rheological switch with the mantle wedge at lower $\mathrm{T}$ than basalts (Figs. 4c,d), their arrival along the plate interface will indeed

453 localize strain and thus deactivate basalt accretion.

As a result of progressive cooling of the subduction zone, potential accretion of HT soles further downdip can be predicted for a few more My after subduction initiation (Fig. 5b). Such rocks, however, are not accreted below ophiolites and/or not exhumed, which could be due to rock densities exceeding mantle values (thermodynamic modelling shows that this will be the case for basalt at $800^{\circ} \mathrm{C}$ for $\mathrm{P}>1.2 \mathrm{GPa}$ ), to dynamics associated with melting at depth (Faccenda, 2014) and/or to the resumption of full coupling between the plates (Syracuse et al., 2010) dragging down these rocks irreversibly.

In contrast, later and further downdip, the mantle wedge will get colder, more hydrated and therefore more buoyant while transiently remaining fairly strong (i.e., still mechanically strongly coupled). HT eclogites and the heterogeneously hydrated/weakened mantle wedge may thus reach broadly equivalent viscosities towards the end of subduction infancy, thereby favouring mechanical coupling, rock mixing and fast (buoyant) joint exhumation. This could explain the anticlockwise, short-lived exhumation of HT eclogites in serpentinite mélanges at depths of 50-60 km and $~ 5 \mathrm{My}$ after subduction nucleation (Figs. 3a, 5c; e.g., Franciscan complex or Serpentinite mélange of Cuba: Garcia-Casco et al., 2006).

\subsubsection{Exhumation of HT soles and basal peridotites: the depth conundrum}

This study highlights the contrast between the juxtaposition of HT soles and basal peridotites at 25-35 km (assuming purely lithostatic P estimates) and the final ophiolite thickness $(\leq 10-15 \mathrm{~km})$. Whether this can be explained by mantle thinning (Casey and Dewey, 1984; Dewey and Casey, 2013) or relative exhumation (or both) has been a matter of speculation (e.g., the "conundrum of Samail"; Hacker and Gnos, 1997). Mantle thinning would have to be concentrated within the basal peridotites (500-1000 $\mathrm{m}$ thick at present) as the rest of the mantle section is mostly undeformed 
477 (Ceuleneer et al., 1988; Nicolas et al., 2000), and does not explain how metamorphic soles get 478 accreted.

479 Based on the pressure difference between the HT and LT soles and on the similar P-T 480 conditions retrieved from HT soles and basal peridotites (e.g., Jamieson, 1981; McCaig, 1983; this 481 study), the reconstruction of figure 5 depicts their relative exhumation with respect to the rest of the 482 overlying oceanic lithosphere, thanks to buoyancy/rheology contrasts (and through successive 483 stacks: HTsolelperidotite, then LTsole\HTsolelperidotite). The lower density of the slices would 484 account for their exhumation with respect to the overlying mantle, while the rheology (viscosity) 485 constrasts above and below the slices would favour strain localization. Relative exhumation is also 486 supported by the existence of rare blueschist facies overprints on HT soles underlain by blueschist 487 facies rocks (e.g., Turkey; Plunder et al., 2015, 2016), indicating that, in some cases, the HT sole is 488 not immediately exhumed and stagnates at depth (which would not be the case if the mantle was 489 systematically thinned).

490 An alternative explanation to the depth conundrum could be that the $\sim 1 \mathrm{GPa}$ pressure estimate 491 for the HT soles corresponds to overpressure arising from strongly coupled lithologies (i.e., dry 492 mantle against basalt; McCaig, 1983). Depths attributed to the deformation of HT soles and basal 493 peridotites could then be reduced by up to a factor of 2 (Petrini and Podladchikov, 2000), matching 494 both the depths/pressures of LT soles and final ophiolite thickness $(\sim 10-15 \mathrm{~km})$. Whether such 495 rocks, affected by strong ductile deformation, may sustain excess dynamic pressure is unclear and 496 could be tested with numerical models (with limitations discussed in section 5.1.2). Overpressure 497 would not, however, affect the conclusions of this study regarding mechanical coupling, accretion 498 or the existence of rheological switches.

\subsubsection{Are metamorphic soles formed beneath supra-subduction ophiolites?}

While the proposed mechanism emphasizes the importance of rheology during subduction 
Nicolas et al., 2000) and others supporting an entirely supra-subduction origin (Stern and Bloomer, 1992). In the first hypothesis, formation of oceanic lithosphere shortly predates intra-oceanic subduction (via near-ridge, detachment or transform fault inversion; Boudier et al., 1988), while in the second hypothesis intra-oceanic spontaneous subduction (often assumed to take place at transform faults) triggers the formation of supra-subduction lithosphere by mantle upwelling (e.g., Stern and Bloomer, 1992). The interplay between lithology/rheology, T (and P) and mechanical coupling of our proposed mechanism could in principle operate through either inversion of small oceanic basins or mantle upwelling following spontaneous subduction initiation. The second scenario, however, less easily explains the systematic juxtaposition of HT soles onto LT soles (and the sharp lithological divide between them), as well as the slightly younger and more dispersed ages of the metamorphic soles when compared to those of the ophiolite crust (Fig. 1d; Wakabayashi and Dilek, 2000, 2003). Metamorphic sole formation may thus question the popular spontaneous subduction initiation model (Stern and Bloomer, 1992).

\subsection{Rheological implications}

An important inference from this model is that the effective rheologies of the mantle and crust are similar at $\sim 800^{\circ} \mathrm{C}$ and $\sim 1 \mathrm{GPa}$ in the presence of fluids. This is an important anchor point for experimental rock mechanics, supporting the validity of extrapolations from laboratory experiments performed orders of magnitude faster than in nature. Although the viscosity-temperature path of the mantle wedge (from i to f; Fig. 4b) or location of the first rheological switch are not determined with precision yet, their location (at $\pm 50^{\circ} \mathrm{C}$ and $\sim 1$ order of magnitude in viscosity) further supports the convergence of the experimental grain size dependent flow laws at $\sim 800^{\circ} \mathrm{C}$ (i.e., at the temperature of HT sole formation; Fig. 4d).

Figure 5 also highlights the importance, for strain localization during subduction infancy, of lubrication by hydrous phases (Regenauer-Lieb et al., 2001; Dymkova and Gerya, 2013) and grain size reduction (Linckens et al., 2011b; Hirth and Kohldstedt, 2015). Viscosity estimates for sole formation (Fig. 4d) match those inferred for the nucleation of throughgoing low viscosity shear 
531 zones ( $10^{20}$ Pa.s; Regenauer-Lieb et al., 2001). Although mantle wedge rheology likely depends on

532 the extent of serpentinization and higher $\mathrm{T}$ ductile deformation, the similarity of ophiolite soles

533 worldwide suggests that regional variations (e.g., incoming material, convergence rates, effective 534 fluid release) are averaged out.

535 The presence of a warm oceanic lithosphere (i.e., < 3 My and/or rejuvenated; Hacker, 1990;

536 Duretz et al., 2015; supplementary material) appears to be an important requirement for 537 metamorphic sole formation. Their formation is probably inhibited for older lithospheres, not 538 because they are too cold (warm conditions will be met deeper down) but because the plate 539 interface will be too decoupled. On the other hand, previous studies suggested that one-sided 540 intraoceanic subduction initiation requires significant mantle cooling and subsequent weakening 541 (Crameri et al., 2012). Too strong mechanical coupling, during subduction infancy, would favour 542 double-sided subduction as in the Archean (Sizova et al., 2010 and references therein). This 543 potentially explains why ophiolite soles older than the Neo-proterozoic are missing.

544 These findings also bear important implications for mechanisms of sediment or seamount 545 underplating (i.e., transient episodes of strong coupling may control, in long-lived subduction 546 systems, the potential accretion/exhumation of HP-LT rocks, including eclogites; Kimura and 547 Ludden, 1995; Agard et al., 2007), variably hydrated mantle wedge rheologies (Faccenda, 2014) 548 and for geochemical budgets of volatile fluxing during (hot) subduction (Ishikawa et al., 2005; 549 Sizova et al., 2010).

\section{Conclusions}

Combining structure-lithology-P-T-time data from metamorphic soles with flow laws derived from experimental rock mechanics, we herein (i) outline the existence of two major, systematic rheological switches across the subduction interface (mantle wedge vs. basalts, then mantle wedge vs. sediments), (ii) propose that they control slab penetration and the successive formation of HT 
558 then LT metamorphic soles and (iii) provide a tentative reconstruction of metamorphic sole

559 accretion during subduction infancy.

560 This reconstruction provides a generic explanation for the ubiquitous formation of

561 metamorphic soles and emphasizes how slab progression is hindered, during subduction infancy, by

562 progressive changes in the mechanical properties of the cooling plate interface, until the interface

563 becomes fully decoupled. Metamorphic sole formation and accretion would not so much result from

564 a transient HT event (i.e., an 'ironing' effect), but from the existence of transiently similar rheologies

565 and strong coupling during subduction infancy.

566 This study sheds light on early slab dynamics and on the role of transient mechanical coupling

567 along the plate interface (i.e., such transient episodes may also control accretion/exhumation of HP-

568 LT rocks in mature subduction systems) and provides a testable hypothesis for thermo-mechanical

569 models. The proposed mechanism also strengthens the applicability of experimentally-derived flow

570 laws for the mantle and mafic crust: although calibrated at much higher strain rates, they appear to

571 be in remarkable agreement with natural data at $\sim 800^{\circ} \mathrm{C}$ (and $\sim 1 \mathrm{GPa}$ ).

572

573 
576 This work was funded through the Agence nationale de la recherche (ANR-10-BLAN-0615) and 577 through Institut Universitaire de France (grant to P.A.). We are grateful to colleagues from the 578 O:NLAP ANR project for fruitful and enthusiastic discussions. An earlier version of this manuscript 579 benefited from the constructive remarks of our friend and colleague E. Burov, who sadly passed 580 away, and A. Schubnel. This work also benefited from discussions with scientists from the ZIP 581 project (REA grant agreement no. 604713 (ZIP "Zooming In between Plates") from the People 582 Programme (Marie Curie Actions) of the European Union's Seventh Framework Programme 583 584 FP7/2007-2013). 


\section{REFERENCES}

Agard, P., Jolivet, L., Vrielynck, B., Burov, E., Monie, P., 2007. Plate acceleration: The obduction trigger? Earth Planet. Sci. Letters 258, 428-441.

Agard et al., Agard, P., Yamato, P., Jolivet, L. \& Burov, E. 2009. Exhumation of oceanic blueschists amd eclogites in subduction zones: Timing and mechanisms. Earth-Sci. Rev. 92, 53-79.

Baldwin, J.A., Powell, R., Brown, M., Moraes, R. and Fuck, R.A., 2005. Modelling of mineral equilibria in ultrahigh-temperature metamorphic rocks from the Anápolis-Itaucu Complex, central Brazil. J. Metamorph. Geol., 23, p. 511-531.

Boudier, F., Ceuleneer, G. \& Nicolas, A. 1988. Shear zones, thrusts and related magmatism in the Oman ophiolite : Initiation of thrusting on an oceanic ridge. Tectonophysics 151, 275-296.

Casey, J. F. \& Dewey, J. 1984, Initiation of subduction zones along transform and accreting plate boundaries, triple-junction evolution, and forearc spreading centres: implications for ophiolitic geology and obduction Geol. Soc. Lond. Spec. Pub. 13, 269-290.

Çelik, Ö.F., Marzoli, A., Marschik, R., Chiaradia, M., Neubauer, F. and Öz, I., 2011. Early-Middle Jurassic intra-oceanic subduction in the İzmir-Ankara-Erzincan Ocean, Northern Turkey: Tectonophysics, 509, p. 120-134, doi: 10.1016/j.tecto.2011.06.007.

Ceuleneer, G., Nicolas, A. and Boudier, F., 1988. Mantle flow patterns at an oceanic spreading centre: the Oman peridotites record. Tectonophysics 151, 1-26.

Coleman, R.G., 1981. Tectonic setting for ophiolite obduction in Oman. J. Geophys. Res. 86, 24972508.

Crameri, F., Tackley, P. J., Meilick, I., Gerya T. \& Kaus, B. J. P. 2012. A free plate surface and weak oceanic crust produce single-sided subduction on Earth. Geophys. Res. Lett. 39, L03306.

de Capitani, C. \& Petrakakis, K. 2010. The computation of equilibrium assemblage diagrams with Theriak/Domino software. Am. Mineral. 95, 1006-1016.

Dewey, J. 1976. Ophiolite obduction. Tectonophysics. 31, 93-120.

Dewey, J.F. and Casey, J.F., 2013. The sole of an ophiolite: the Ordovician Bay of Islands Complex, Newfoundland: Journal of the Geological Society, London, 170, p. 715-722, doi: 10.1144/jgs2013-017.

Diener, J.F.A., Powell, R., White, R.W. and Holland, T.J.B., 2007. A new thermodynamic model for clino- and orthoamphiboles in the system Na2O-CaO-FeO-MgO-Al2O3-SiO2-H2O-O. J. Metamorph. Geol., 25, p. 631-656, doi: 10.1111/j.1525-1314.2007.00720.x.

Diener, J. F. A. \& Powell, R. 2012. Revised activity-composition models for clinopyroxene and amphibole. J. Metamorph. Geol. 30, 131-142. 
Duretz, T., Agard, P., Yamato, P., Ducassou, C., Burov, E.B., Gerya, T.V. 2015. Thermo-mechanical modeling of the obduction process based on the Oman Ophiolite case, Gondwana Research, doi:10.1016/j.gr.2015.02.002.

Escartin, J., Hirth, G. \& Evans, B. W. 2001. Strength of slightly serpentinised peridotites: implications for the tectonics of oceanic lithosphere, Geology 29, 1023-1026.

Faccenda, M. 2014. Water in the slab: A trilogy, Tectonophysics 614, 1-30.

Faul, U. H., Jackson, I. 2007. Diffusion creep of dry, melt-free olivine, J. Geophys. Res., 112, B04204, doi:10.1029/2006JB004586.

García-Casco, A., Torres-Roldán, R. L., Iturralde-Vinent, M., Millán, G., Cambra, K. N., Calisalvo, C. L., \& Vega, A. R. 2006. High pressure metamorphism of ophiolites in Cuba. Geol. Acta 4, 63-88.

Getsinger, A. J. \& Hirth, G. 2014. Amphibole fabric formation during diffusion creep and the rheology of shear zones. Geology 42, 535-538.

Gnos, E. 1998. Peak Metamorphic Conditions of Garnet Amphibolites Beneath the Semail Ophiolite: Implications for an Inverted Pressure Gradient. Int. Geol. Rev. 40, 281-304.

Green, E. C. R., White, R. W., Diener, J. F. A., Powell, R., Holland, T. J. B., Palin, R. M., 2016. Activity-composition relations for the calculation of partial melting equilibria for metabasic rocks. J. Metamorph. Geol., accepted for publication.

Gurnis, M., Hall, C. \& Lavier, L. 2004. Evolving force balance during incipient subduction. Geochem, Geophys. Geosyst. 5, Q07001.

Hacker, B.R., 1990. Simulation of the Metamorphic and Deformational History of the Metamorphic Sole of the Oman Ophiolite, J. Geophys. Res., 95, 4895-4907.

Hacker, B. R., Mosenfelder, J. L. \& Gnos, E. 1996. Rapid emplacement of the Oman ophiolite: Thermal and geochronologic constraints. Tectonics. 15, 1230-1247.

Hacker, B. R. \& Gnos, E. 1997. The conundrum of samail: explaining the metamorphic history. Tectonophysics 279, 215-226.

Hansen, L.N., Zimmerman, M.E., Kohlstedt, D.L., 2011. Grain boundary sliding in San Carlos olivine: flow law parameters and crystallographic-preferred orientation. J. Geophys. Res.116, B08201.

Hilairet, N., Reynard, B., Wang, Y., Daniel, I., Merkel, S., Nishiyama, N., Petitgirard, S. 2007. High-pressure creep of serpentine, interseismic deformation and initiation of subduction. Science. 318, 1910-1913.

Hirth, G., Kohlstedt, D.L., 2003. Rheology of the upper mantle and the mantle wedge: a view from the experimentalists. In: Inside the Sub-duction Factory (Ed. Eiler, J.), Geophys. Monogr. 138,, American Geophysical Union, Washington, D.C., 83-105. 
Hirth, G. \& Kohlstedt, D. L. 2015. The stress dependence of olivine creep rate: Implications for extrapolation of lab data and interpretation of recrystallized grain size. Earth Planet. Sci. Lett. 418, 20-26.

Holland, T.J.B. \& Powell, R. 1998. An internally consistent thermodynamic data set for phases of petrological interest. J. Metamorph. Geol. 16, 309-343.

Homburg, J.M., Hirth, G., Kelemen, P.B. 2010. Investigation of the strength contrast at the Moho: A case study from the Oman Ophiolite, Geology, 38, 679-682.

Ishikawa, T., Fujisawa, S., Nagaihi, K. \& Masuda T. 2005. Trace element characteristics of the fluid liberated from amphibolite-facies slab: Inference from the metamorphic sole beneath the Oman ophiolite and implication for boninite genesis. Earth Planet. Sci. Lett. 240, 355-377.

Jamieson, R. A. 1981. Metamorphism during ophiolite emplacement - the petrology of the St Anthony Complex, J. Petrol. 22, 397-443.

Jamieson, R. A. 1986. P-T paths from high temperature shear zones beneath ophiolites. J. Metam. Geol 4, 3-22.

Karato, S. 2010. Rheology of the Earth's mantle: A historical review, Gondwana Research, 18, 1745.

Kimura, G. \& Ludden, J. 1995. Peeling oceanic crust in subduction zones. Geology 23, 217-220.

Linckens, J., Herwegh, M. \& Müntener, O. 2011. Linking temperature estimates and microstructures in deformed polymineralic mantle rocks. Geochem, Geophys. Geosyst. 12, Q08004.

Linckens, J., M. Herwegh, O. Müntener, and I. Mercolli (2011), Evolution of a polymineralic mantle shear zone and the role of second phases on the localization of deforma- tion, $\mathrm{J}$. Geophys. Res., 116, B06210, doi:10.1029/ 2010JB008119.

McCaig, A. M. 1983. P-T conditions during emplacement of the Bay of Islands ophiolite complex. Earth Planet. Sci. Lett. 63, 459-473.

Michibayashi, K., Mainprice, D. 2004. The role of pre-existing mechanical anisotropy on shear zone development within oceanic mantle lithosphere: an example from the Oman ophiolite. J. Petrol., 45, 405-414.

Nicolas, A., 1989. Structures in Ophiolites and Dynamics of Oceanic Lithosphere (Petrology and Structural Geology). Kluwer, Dordrecht.

Nicolas, A., Boudier, F., Ildefonse, B., Ball, E., 2000. Accretion of Oman and United Arab Emirates ophiolite - Discussion of a new structural map. Mar. Geophys. Res., 21, 147-179.

Petrini K, \& Podladchikov Y. 2000. Lithospheric pressure-depth relationship in compressive regions of thickened crust. J. Metamorph. Geol., 18, 67-77. 
689

690

691

692

693

694

695

696

697

698

699

700

701

702

703

704

705

706

707

708

709

710

711

712

713

714

715

716

717

718

719

720

721

722

723

724

Plunder, A., Agard, P., Chopin, C., Pourteau, A., \& Okay, A. I. 2015. Accretion, underplating and exhumation along a subduction interface: From subduction initiation to continental subduction (Tavşanlı zone, W. Turkey). Lithos 226, 233-254.

Plunder, A., Agard, P., Chopin, C., Soret, M., Okay, A.I., \& Whitechurch, H. 2016. Metamorphic sole formation, emplacement and blueschist-facies overprint: early subduction dynamics witnessed by western Turkey ophiolites. Terra Nova, in press.

Regenauer-Lieb, K., Yuen, D. A. \& Branlund, J. 2001. The Initiation of Subduction: Criticality by Addition of Water? Science 294, 578-580.

Rioux, M. et al.. 2013. Tectonic development of the Samail ophiolite : High-precision U-Pb zircon geochronology and $\mathrm{Sm}-\mathrm{Nd}$ isotopic constraints on crustal growth and emplacement. J. Geophys. Res. 118, 2085-2101.

Roberts, N.M.W., Thomas, R.J., Jacobs, J., 2016. Geochronological constraints on the metamorphic sole of the Semail ophiolite in the United Arab Emirates. Geoscience Frontiers, in press.

Searle, M. P. \& Malpas, J. 1980. Petrochemistry and origin of sub-ophiolitic metamorphic and related rocks in the Oman Mountains. J. Geol. Soc. 139, 235-248.

Sizova, E., Gerya, T., Brown, M. \& Perchuk, L. L. 2010. Subduction styles in the Precambrian: Insight from numerical experiments. Lithos 116, 209-229.

Spray, J. G. 1984. Possible causes and consequences of upper mantle decoupling and ophiolite displacement Geol. Soc. Lond. Spec. Pub. 13, 255-268.

Stern, R., J. \& Bloomer, S. 1992. Subduction zone infancy: examples from the Eocene Izu-BoninMariana and Jurassic California arcs. Geol. Soc. of Am. Bull. 104, 1621-1636.

Stern, R. J. 2004. Subduction initiation: spontaneous and induced. Earth Planet. Sc. Lett. 226, 275292.

Syracuse, E. M., van Keken, P. E. \& Abers, G. A. 2010. The global range of subduction zone thermal models. Phys. Earth Planet. Int. 183, 73-90.

Tasaka, M., Hiraga, T., Michibayashi, K. 2014. Influence of mineral fraction on the rheological properties of forsterite+enstatite during grain size sensitive creep: 3. Application of grain growth and flow laws on peridotite ultramylonite, J. Geophys. Res. Solid Earth, 119, 840857, doi:10.1002/2013JB010619.

Ulmer, P., \& Trommsdorff, V. Serpentine stability to mantle depths and subduction-related magmatism. Science 268, 858-861 (1995).

Wakabayashi, J., and Dilek, Y., 2000, Spatial and temporal relationships between ophiolites and their metamorphic soles: A test of models of forearc ophiolite genesis, in Dilek, Y., Moores, E.M., Elthon, D., and Nicolas, A., eds., Ophiolites and Oceanic Crust: New Insights from Field Studies and the Ocean Drilling Program: Boulder, Colorado, Geological Society of America Special Paper 349, p. 53-64. 
725 Wakabayashi, J. \& Dilek, Y. 2003. What constitutes «emplacement of an ophiolite ?: Mechanisms and relationship to subduction initiation and formation of metamorphic soles. Geol. Soc. Lond. Spec. Pub. 218, 427-447.

728 White, R.W., Powell, R. and Holland, T.J.B., 2007. Progress relating to calculation of partial 729 melting equilibria for metapelites. J. Metamorph. Geol., 25, p. 511-527, doi: 10.1111/j.15251314.2007.00711.x.

731 Williams, Smyth, W. R., 1973. Metamorphic aureoles beneath ophiolite suites and Alpine 732 733 peridotites: tectonic implications with west Newfoundland examples. Am. J. Sci. 273, 594621.

Yuen, D.A., Fleitout, L., Schubert, G., Froidevaux, C., 1978. Shear deformation zones along major 736 
Fig. 1

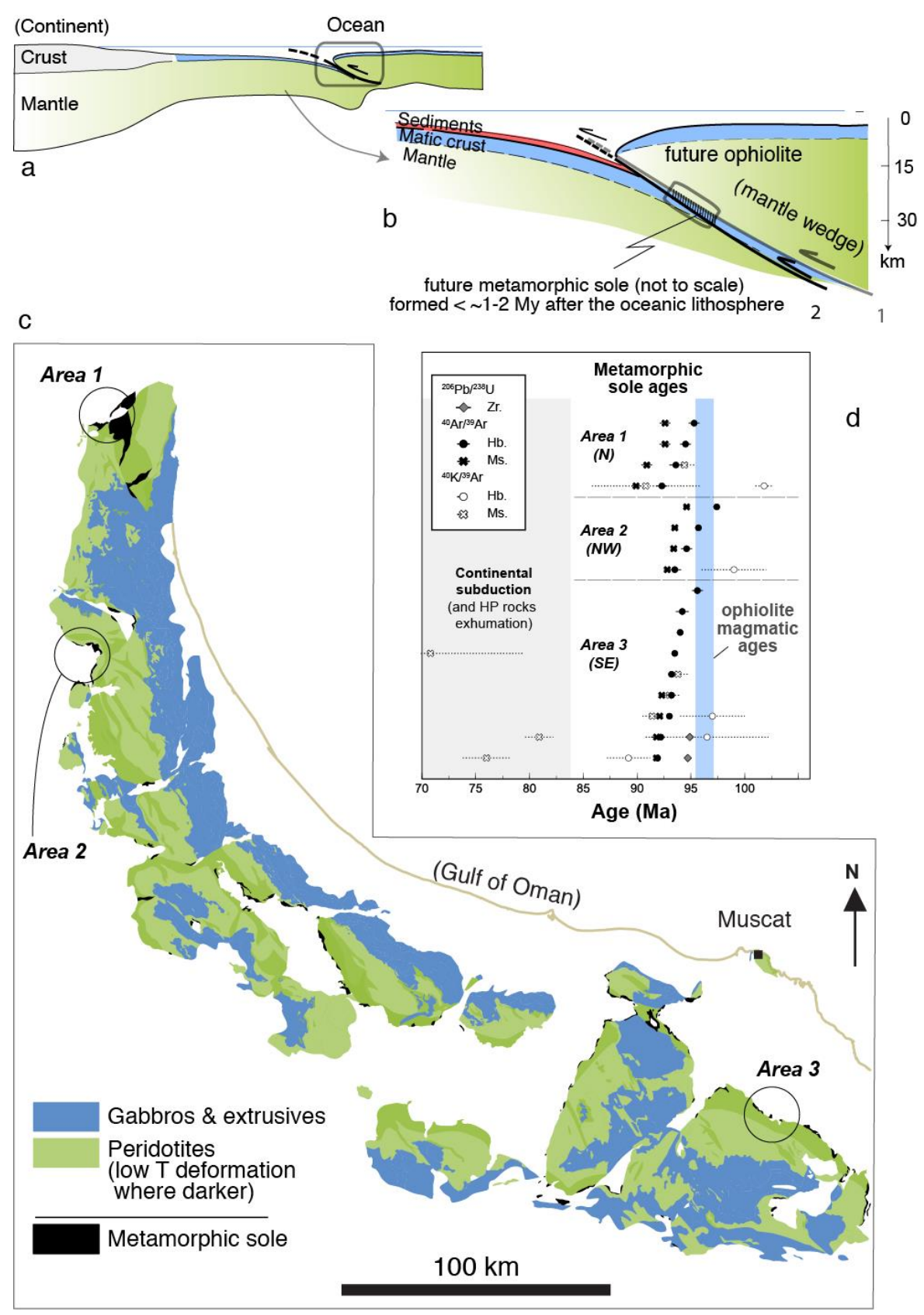

Figure 1

(a) Geodynamic setting of metamorphic sole formation during subduction infancy, following intraoceanic subduction initiation. The later geodynamic evolution will lead to continental subduction and obduction s.s. (i.e., emplacement of the oceanic lithosphere onto continental lithosphere; after Agard et al., 2007); (b) Close-up view of Fig. 1a: the formation and accretion of metamorphic soles imply a shift of the subduction interface during subduction initiation (from thrust 1 to thrust 2); (c) simplified geological map highlighting the striking continuity of the metamorphic sole beneath the mantle of the Oman ophiolite (modified after Nicolas et al., 2000); (d) age constraints for metamorphic sole formation along the Oman ophiolite (Hb: hornblende; Ms: white mica; $\mathrm{Zr}$ : zircon; see Table 1 for references). Radiometric ages for the ophiolite are shown for comparison (after Rioux et al., 2013; see discussion in section 5.2). 


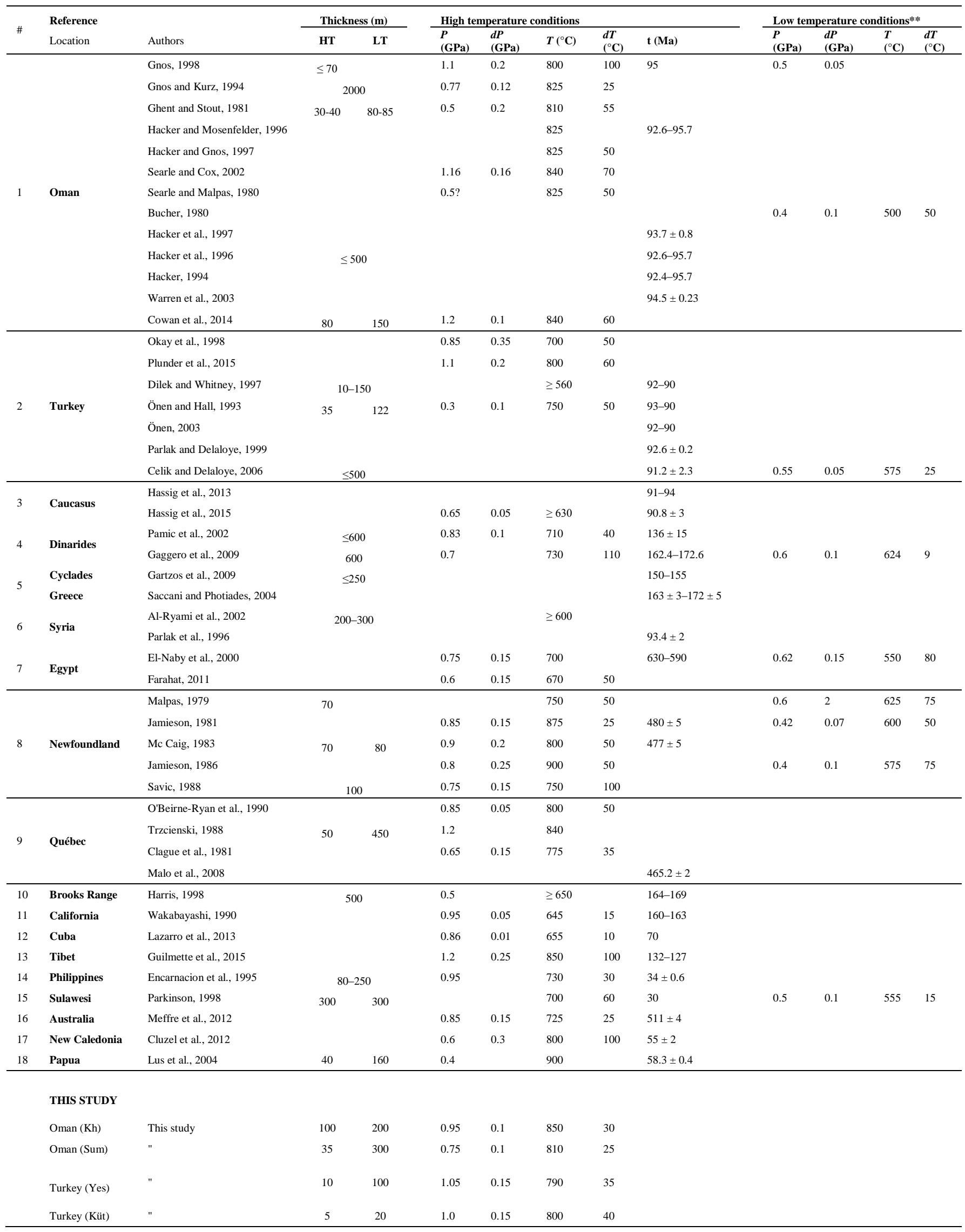

\section{Table 1}

763 Worldwide compilation of data on metamorphic soles (temperature, pressure, metamorphic ages and thicknesses; **: estimates from amphibole-plagioclase thermometry, amphibole barometry or other methods). See supplementary material for references. Abbreviations: Kh: Khubakhib; Küt: Kütahya; Sum: Sumeini; Yes: Yesilova). 
Fig. 2

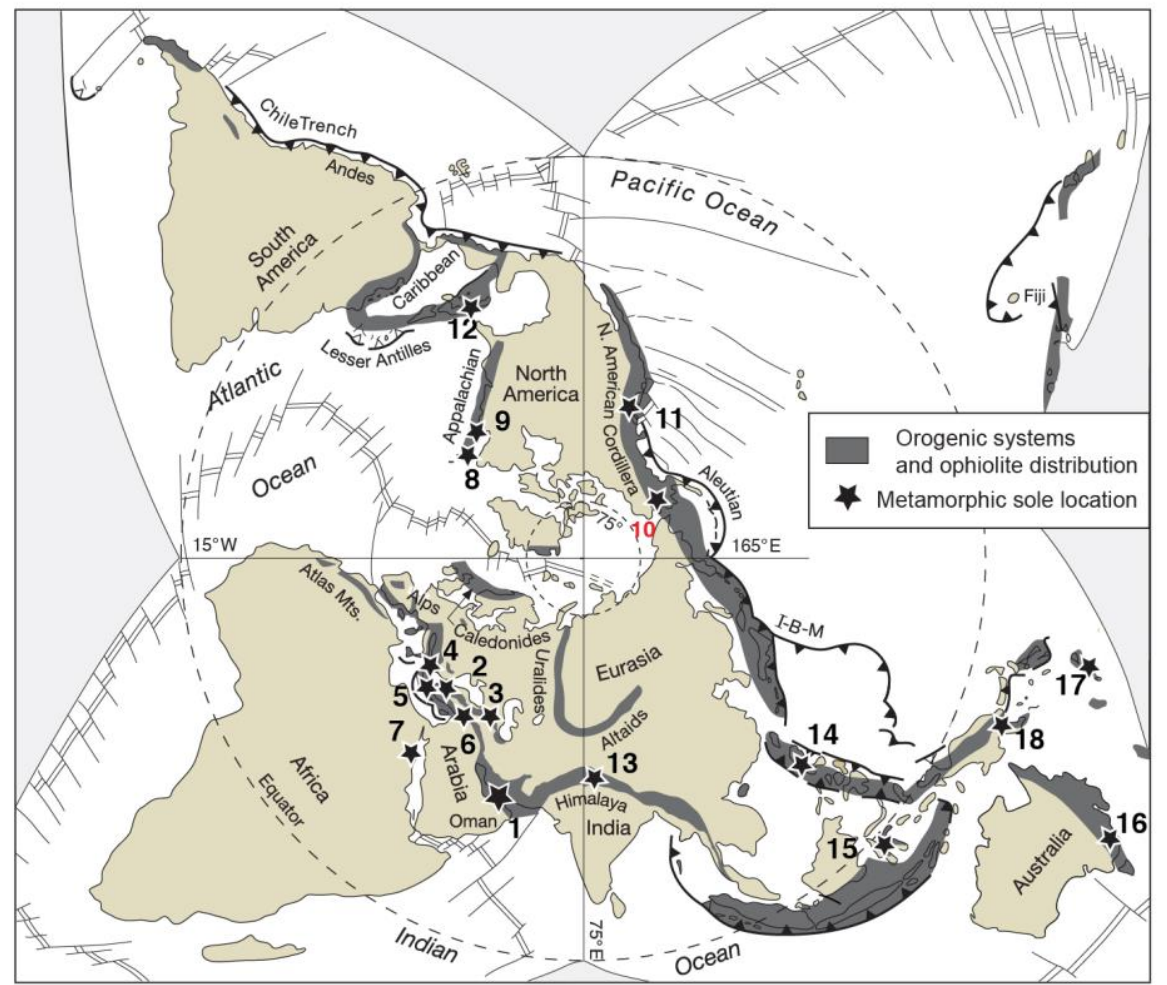

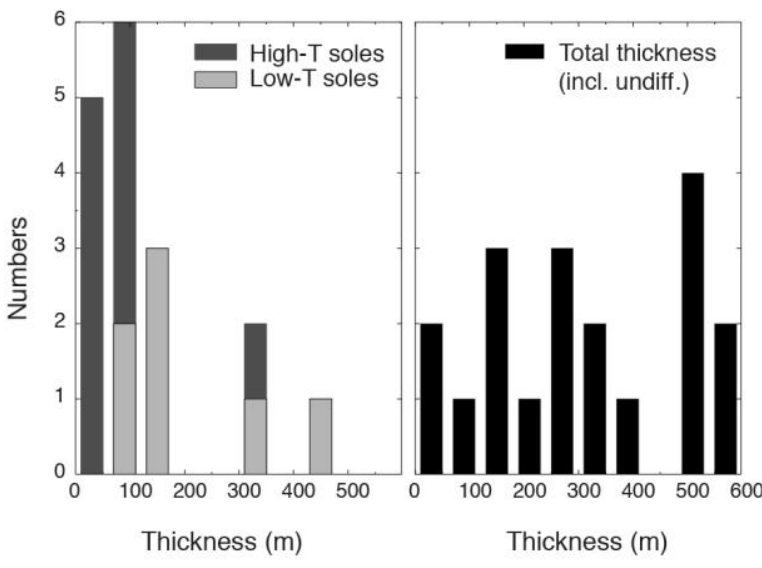

b

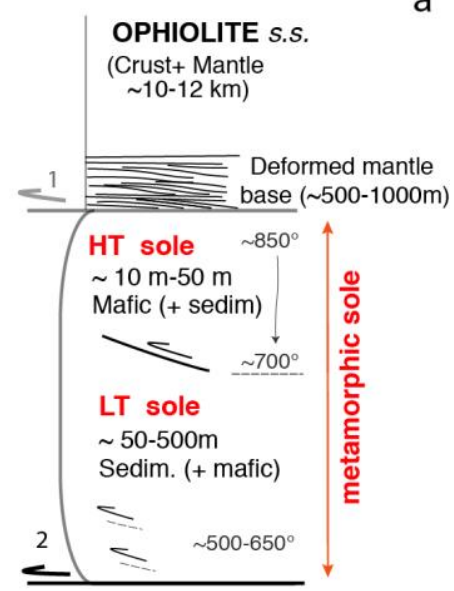

d

\section{Figure 2}

(a) Location of metamorphic soles and of the main large-scale obducted ophiolites worldwide (spanning late Proterozoic to Phanerozoic times); (b) and (c): histograms of thicknesses for metamorphic soles (after Table 1); (d) general structure of ophiolite soles (not to scale), emphasizing differences between the HT and LT sections. (temperature indications after Fig. 3a). Note the strongly deformed mantle section at the base of the ophiolite. Thrusts 1 and 2 as in figure $1 b$. 
Fig. 3

a

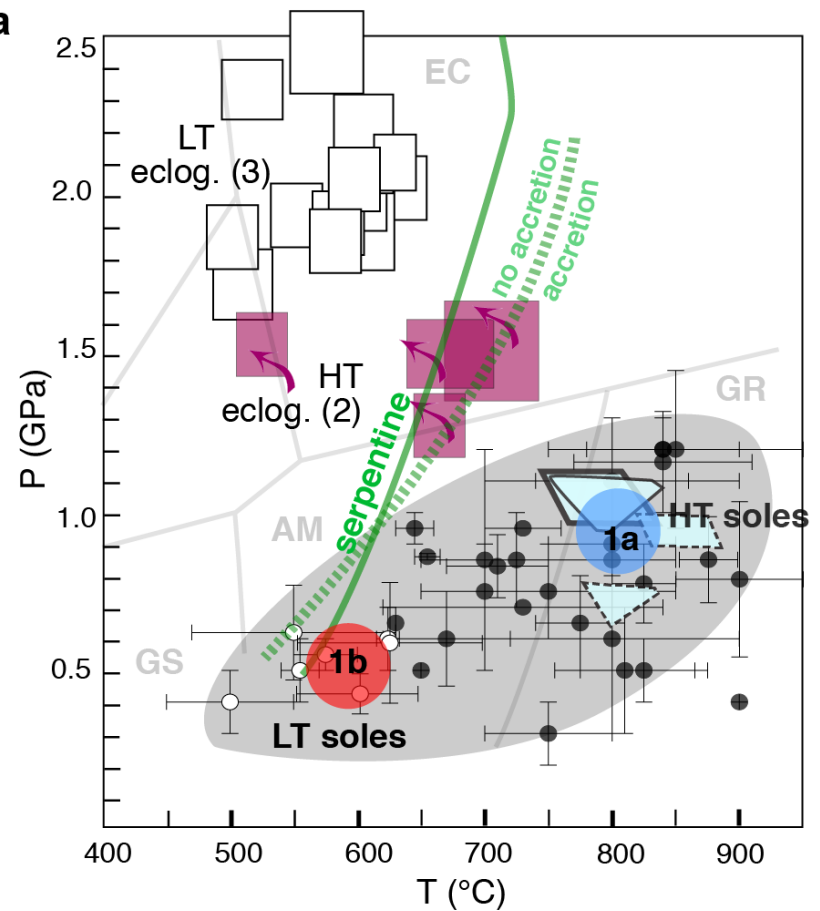

b

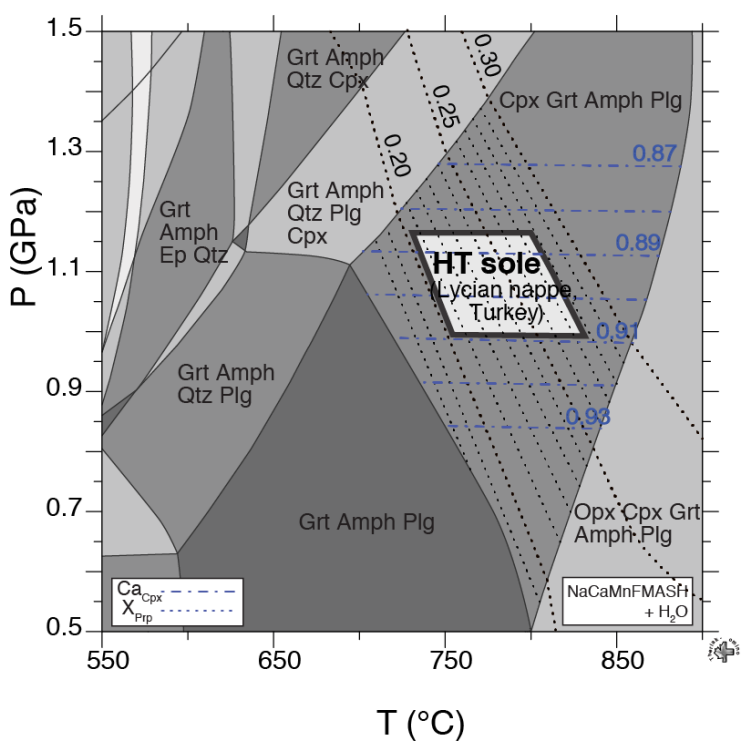

\section{Figure 3}

(a) Compilation of pressure-temperature data for HT (black) and LT (white) metamorphic soles (see Table 1; all are enclosed in the grey shaded area). P-T conditions for representative eclogites (HT: purple; LT: white) are also given for comparison (after Agard et al., 2009). Arrows outline counterclockwise P-T paths for HT eclogites. Boxes in the HT sole domain correspond to phase diagram calculations in this study. Plain boxes: results for two sample locations in Turkey (Kütahya and Yesilova); dashed boxes: results for two locations in Oman (Sumeini and Khubakhib). The diamond-shaped box with a thicker contour correponds to the estimate for the HT sole sample from Yesilova described in the text and in figure 3b. Samples have the following molar proportions (\%): Kutahya: Si (46.92), Al (16.14), Fe (9.98), Mg (10.08), Ca (10.49), Na (6.39) / Yesilova: Si (44.29), $\mathrm{Al}$ (16.77), Fe (7.68), Mn (0.45), Mg (15.52), Ca (10.37), Na (4.14)/ Sumeini: Si(43.24) Al(15.66) $\mathrm{Fe}(10.46) \mathrm{Mg}(11.37) \mathrm{Ca}(16.81) \mathrm{Na}(2.46)$ / Khubakhib: $\mathrm{Si}$ (44.85) Al (15.67) Fe(8.82) $\mathrm{Mg}(11.51) \mathrm{Ca}$ (14.36) $\mathrm{Na}$ (4.79). (b) Phase diagram calculated in the $\mathrm{Na}_{2} \mathrm{O}-\mathrm{CaO}-\mathrm{MnO}-\mathrm{FeO}-\mathrm{MgO}-\mathrm{Al}_{2} \mathrm{O}_{3}-\mathrm{SiO}_{2}-$ $\mathrm{H}_{2} \mathrm{O}$ chemical system for a MORB-type HT metamorphic sole (YE1302b; Lycian ophiolite, W. Turkey). The studied equilibrium peak assemblage (i.e. garnet-clinopyroxene-amphiboleplagioclase) is stable within a P-T field refined using mineral isopleths (e.g., pyrope content in garnet: $X_{P r p}$; Calcic component in clinopyroxene: $\left.C a_{C p x}\right)$ to $1.08 \pm 0.1 \mathrm{GPa}$ and $780 \pm 40{ }^{\circ} \mathrm{C}$. Abbreviations for minerals with solid solutions: Amph: amphibole; Cpx: clinopyroxene; Ep: epidote; Grt: garnet; Opx: orthopyroxene; Plg: plagioclase; Qtz: quartz. 

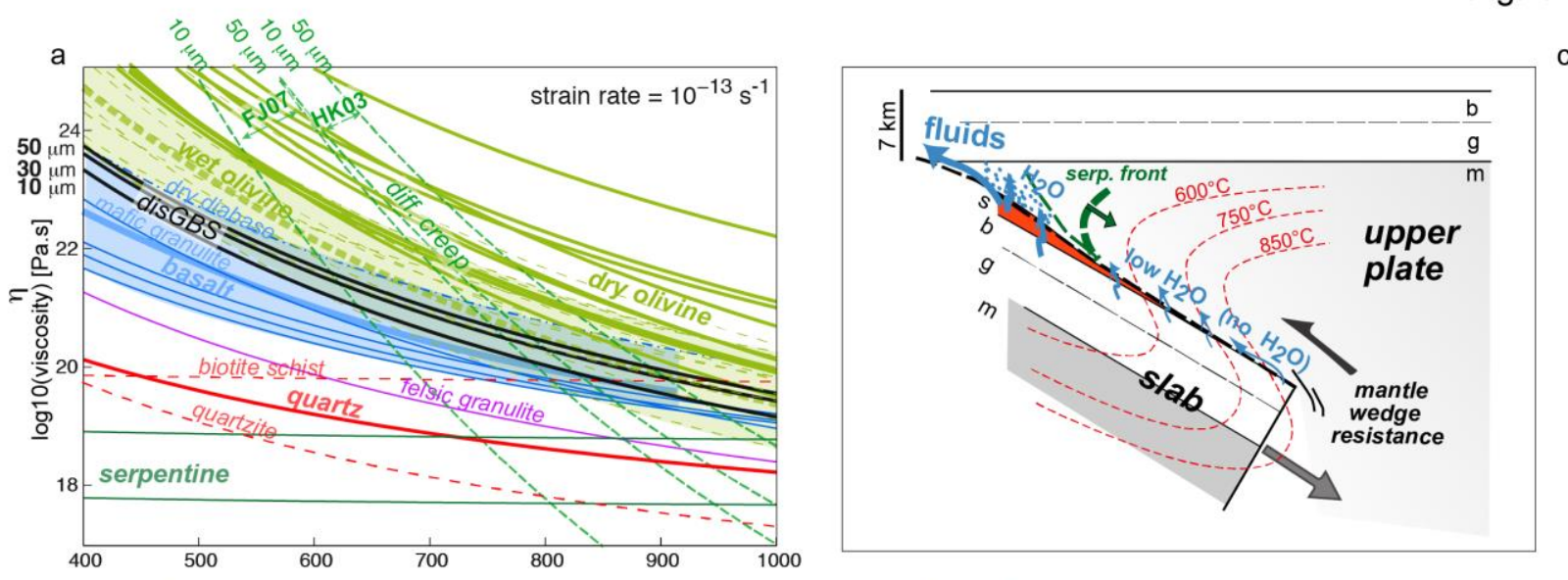

C
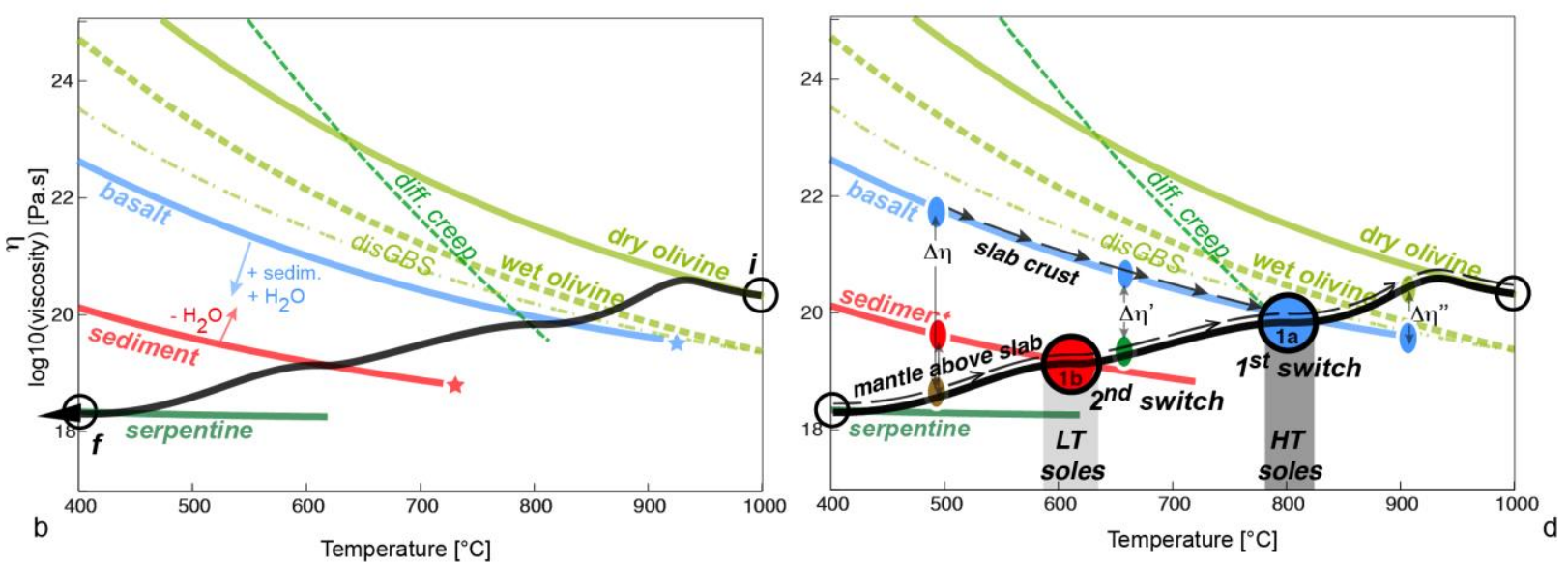

\section{Figure 4}

(a) Calculated temperature dependency of effective viscosities $(\eta)$ for key plate interface lithologies (peridotite, basalt, sediments and serpentine; see Table 2 and section 3.1 for details) for an average strain rate of $10^{-13} \mathrm{~s}^{-1}$ (after the Oman example; Linckens et al., 2011b). Note the systematic location of the dry and wet olivine dislocation creep flow laws above those for mafic rocks (i.e., basalt, blue overlay). Abbreviations: disGBS: dislocation-accommodated grain boundary sliding; diff creep: diffusion creep; FJ07: Faul and Jackson, 2007; HK03: Hirth and Kohlstedt, 2003. Diffusion creep flow laws have been calculated for two different olivine aggregate grain sizes (10 and $50 \mu \mathrm{m}$ ) corresponding to the extreme values estimated by Linckens et al. (2011b) in Oman mantle ultramylonites.

(b) Plot of averages of published flow laws (after Fig. 4a) showing the qualitative viscosity decrease of a cooling and hydrating mantle wedge, from i to $f$ (see text). Note that the viscosity of incoming crust will tend to decrease (from basalt to sediment) with increasing amounts of sediments and/or with addition of water released from progressive sediment dehydration. Stars mark the inception of melting of basalt and sediments (after Kessel et al., 2005 and White et al., 2007, respectively).

(c) 2D sketch of slab penetration during subduction infancy, emphasizing the importance of fluid liberation from the slab. The dashed green line bounds the stability field of serpentine ("serp. front"; blue dots suggest that only part of this domain may be effectively hydrated). Fluid storage capacity of the mantle wedge decreases downwards (see section 3.2). Background isotherms are taken after 1 My from thermo-kinematic modelling (see supplementary material). Abbreviations: s: sediments (shown here in red, as in Fig. 1b), b: basaltic layer, g: gabbroic layer, m: mantle, serp.: serpentinite; (d) Black arrows outline evolving rheologies of the crust on top of the slab (basalt, then sediment) and of the mantle immediately above the slab (Fig. 4c) when the slab descends during subduction infancy. The rheological contrast across the plate interface between the basaltic crust and mantle wedge evolves from $\Delta \eta$ to $\Delta \eta$ ' and $\Delta \eta$ ". Evolution along the black arrows shows the existence of two rheological switches during subduction infancy, when slab crustal rocks reach viscosities comparable to that of the mantle wedge (dots 1a and 1b; see also Fig. 3a). The temperature range 


\begin{tabular}{|c|c|c|c|c|c|}
\hline Lithology & Authors & $\mathbf{n}$ & A & $\mathbf{Q}$ & $\mathbf{m}$ \\
\hline \multicolumn{6}{|l|}{$\underline{\text { Slab crust }}$} \\
\hline \multicolumn{6}{|l|}{ Sediments } \\
\hline Quartz & Ranalli and Murphy, 1987 & 3 & $6.80 \mathrm{E}-06$ & 156 & \\
\hline Wet quartzite & Kirby and Kronenberg,1987 & 2.3 & $3.20 \mathrm{E}-04$ & 154 & \\
\hline Biotite schist & Kronenberg et al., 1990 & 18 & $1.20 \mathrm{E}-30$ & 51 & \\
\hline Schists & Shea and Kronenberg, 1993 & 31 & $1.30 \mathrm{E}-67$ & 98 & \\
\hline Felsic granulite & Wilks and Carter, 1990 & 3.1 & $8.00 \mathrm{E}-03$ & 243 & \\
\hline $\begin{array}{l}\text { Mafic crust } \\
\text { Basalt }\end{array}$ & $\begin{array}{l}\text { Shelton and Tullis, } 1981 \\
\text { and Hacker and Christie, } 1990\end{array}$ & 3.5 & $1.00 \mathrm{E}-04$ & 250 & \\
\hline Wet diabase & Shelton and Tullis, 1981 & 3.4 & $2.00 \mathrm{E}+04$ & 260 & \\
\hline Dry diabase & Mackwell et al., 1998 & 4.7 & $8.00 \mathrm{E}+00$ & 485 & \\
\hline Diabase & Van Hunen and Van den Berg, 2008 & 3.4 & $2.21 \mathrm{E}-04$ & 260 & \\
\hline Microgabbro & Wilks and Carter, 1990 & 3.5 & $4.85 \mathrm{E}+04$ & 535 & \\
\hline Mafic granulite & Wilks and Carter, 1990 & 4.2 & $1.40 \mathrm{E}+04$ & 445 & \\
\hline \multicolumn{6}{|l|}{ Mantle wedge } \\
\hline Dry olivine & Chopra and Paterson, 1981 & 3.6 & $4.50 \mathrm{E}+00$ & 535 & \\
\hline$"$ & Chopra and Paterson, 1984 & 3 & $1.00 \mathrm{E}+04$ & 520 & \\
\hline “ & Chopra and Paterson, 1984 & 3.5 & $2.50 \mathrm{E}-04$ & 532 & \\
\hline “ & Karato et al., 1986 & 3.5 & $5.40 \mathrm{E}+00$ & 540 & \\
\hline “ & Karato and Wu, 1993 & 3.5 & $2.42 \mathrm{E}+05$ & 554 & \\
\hline “ & Karato and Rubie, 1997 & 3 & $2.40 \mathrm{E}+05$ & 554 & \\
\hline “ & Bussod et al., 1993 & 3.5 & $1.12 \mathrm{E}+05$ & 545 & \\
\hline “ & Hirth and Kohlstedt, 2003 & 3.5 & $1.10 \mathrm{E}+05$ & 548 & \\
\hline “ & Karato and Jung, 2003 & 3 & $1.26 \mathrm{E}+06$ & 524 & \\
\hline “ & Li et al., 2006 & 3 & $4.57 \mathrm{E}+03$ & 554 & \\
\hline “ & Kawazoe et al., 2009 & 3.5 & $1.10 \mathrm{E}+05$ & 550 & \\
\hline Diffusion creep & Hirth and Kohlstedt, 2003 & 1 & $1.5 \mathrm{E}+09$ & 375 & 3 \\
\hline Diffusion creep & Faul and Jackson, 2007 & 1.4 & $2 \mathrm{E}+10$ & 484 & 2 \\
\hline DisGBS & Hirth and Kohlstedt, 2003 & 3.5 & $6.5 \mathrm{E}+03$ & 400 & 2 \\
\hline Wet olivine & Chopra and Paterson, 1981 & 4.4 & $2.76 \mathrm{E}+02$ & 498 & \\
\hline “ & Chopra and Paterson, 1981 & 4 & $2.00 \mathrm{E}+03$ & 471 & \\
\hline “ & Karato et al., 1986 & 3 & $1.50 \mathrm{E}+06$ & 250 & \\
\hline “ & Evans and Kohlstedt, 1995 & 4.5 & $2.60 \mathrm{E}+00$ & 498 & \\
\hline “ & Hirth and Kohlstedt, 1996 & 3.5 & $4.88 \mathrm{E}+06$ & 515 & \\
\hline “ & Mei and Kohlstedt, 2000 & 3 & $4.57 \mathrm{E}+03$ & 470 & \\
\hline “ & Mei and Kohlstedt, 2000 & 3 & $5.01 \mathrm{E}+02$ & 508 & \\
\hline “ & Karato and Jung, 2003 & 3 & $3.63 \mathrm{E}+00$ & 421 & \\
\hline “ & Karato and Jung, 2003 & 3 & $7.94 \mathrm{E}+02$ & 470 & \\
\hline “ & Hirth and Kohlstedt, 2003 & 3.5 & $9.00 \mathrm{E}+01$ & 491 & \\
\hline “ & Hirth and Kohlstedt, 2003 & 3.5 & $1.60 \mathrm{E}+03$ & 520 & \\
\hline “ & Mc Donnell et al., 1999* & 2.14 & $9.10 \mathrm{E}+03$ & 302 & 3 \\
\hline Serpentinite & Hilairet et al., 2007 & 5.8 & $2.51 \mathrm{E}-13$ & 20.8 & \\
\hline$"$ & Hilairet et al., 2007 & 3.8 & $2.51 \mathrm{E}-09$ & 12.1 & \\
\hline
\end{tabular}

Table 2

844 Published flow laws and material creep parameters used to compute the curves of figure 4 b. $n, A, Q$ and $m$ correspond to the stress exponent, pre-exponential factor activation energy and grain size exponent, respectively (*calculated with $\mathrm{X}_{\mathrm{H} 2 \mathrm{O}}=0.05 \mathrm{wt} \%$ ). DisGBS: dislocation-accommodated grain boundary sliding. See supplementary material for references. 


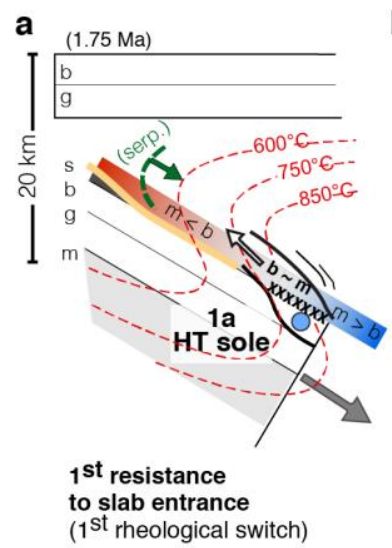

b

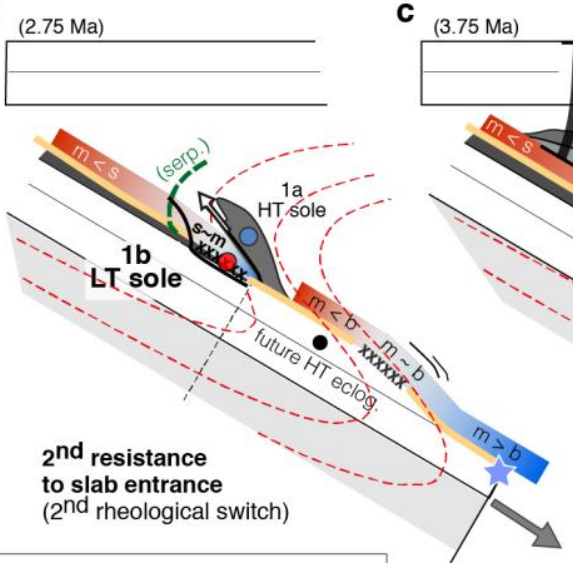

$$
\begin{aligned}
& \begin{array}{lll}
-- & 1 & ++ \\
- & \mid & \text { Viscosity ratio (mantle wedge / crust) }
\end{array} \\
& \text { xxxxxx decoupled interface }
\end{aligned}
$$

\section{Figure 5} few My to shallow near-trench infill;

Model evolution for slab penetration and metamorphic sole formation during subduction infancy (2D sketches and abbreviations as in Fig. 4c; the dashed green line marks the downdip limit of the stability of serpentine, "serp."; the white arrow indicates exhumation): (a) strong interplate mechanical coupling due to the first rheological switch (i.e., when mantle wedge viscosity $\sim$ slab basalt viscosity). Resistance of the mantle wedge to slab penetration triggers the peeling of the slab and HT sole formation. Isotherms and depths are from thermo-kinematic modelling (see supplementary material). Stars indicate incipient melting of basalts and sediments (and plagiogranite formation; Rioux et al., 2013); (b) second rheological switch and LT sole formation. HT metabasalts metamorphosed deeper down in the locked zone are not returned as HT soles (see section 5.2.1). Some HT eclogites may get embedded in a softer mantle wedge and exhumed early in the subduction process; (c) the plate interface progressively 'unzips' by the downward extension of serpentinization until full decoupling. P-T-rheological conditions are such that LT eclogites form along the subduction zone but are only rarely exhumed (see section 5.2.1); (d) close-up view on the tectonic configuration along the plate interface during LT sole accretion, when partial exhumation of the HT sole (shown by the white arrow) juxtaposes it onto the LT sole. Accretion of the LT sole may correspond to the mechanical coupling of the sediments with the mantle above (second rheological switch; option 1) or to the mechanical coupling of the sediments with a progressively weakened mafic HT sole (option 2). See text for details. (e) progressive strain localization results in more superficial decoupling over time within the slab, so that accretion becomes restricted after a 


\section{A. Effective viscosities of plate interface material constrained by rock mechanics \\ A. Effective viscosities of plate interface material constrained by rock mechanics}

\section{APPENDIX. SUPPLEMENTARY MATERIAL}

882

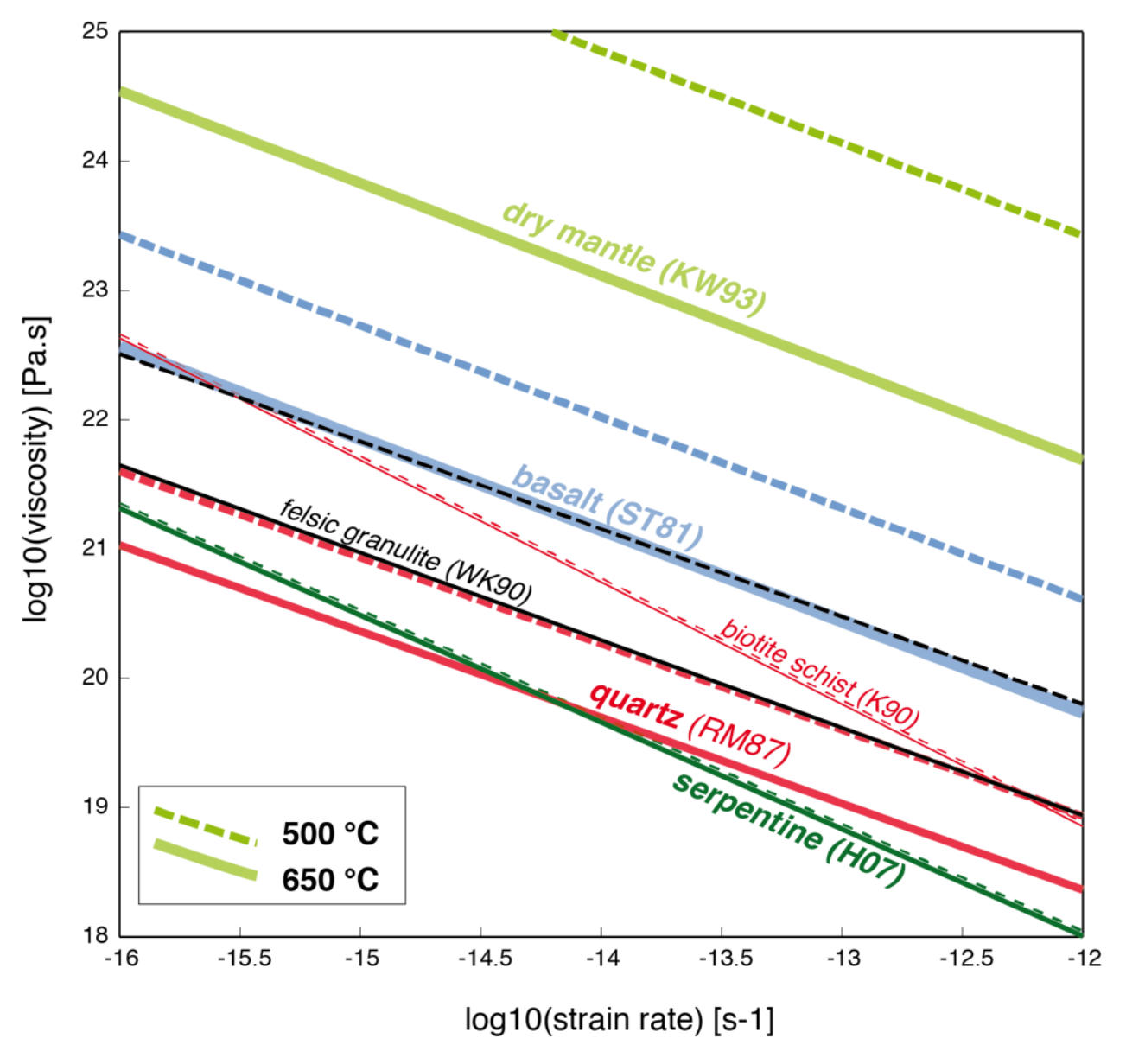

Figure S1. Influence of strain rate on the effective viscosities of selected lithologies at two different temperatures (i.e., 500 and $650^{\circ} \mathrm{C}$; same colors as in figure $4 \mathrm{a}$, except for felsic granulite). Note that the respective positions of the dry mantle, basalt, quartz and serpentine remain unchanged for strain rates $>\sim 10^{14} \mathrm{~s}^{-1}$. Note the stronger dependence on strain rate of serpentine and biotite schist, which are almost independent of temperature (as seen in Fig. 4a). Abbreviations: H07: Hilairet et al., 2007; Karato and Wu, 1993; K90: Kronenberg et al., 1990; RM87: Ranalli and Murphy, 1987; ST81: Shelton and Tullis, 1981; WK90: Wilks and Carter, 1990. 
Thermo-kinematic modelling (after Duprat-Oualid et al., 2013) was performed here in order to 901 place first order constraints on the thermal regime of our tentative reconstruction of slab penetration 902 into the mantle and metamorphic sole formation (Fig. 5). The advantage of such a 2D thermo903 kinematic model, as described in detail in Duprat-Oualid et al. (Fig. S2; 2013), is that it includes a 904 minimum of parameters (i.e., initial thermal ages of the oceanic lithosphere, convergence velocities and slab dips; Fig. S3), in contrast with thermo-mechanical modelling, which is beyond the scope of this study. It also provides a first grip on the depth and duration of the rheological switches outlined in our study (see Fig. S4 below).

\section{Model design and numerical code description}

The morphology of the model is shown in figure S2a. Incoming lower plate material, with a characteristic initial age for the oceanic lithosphere $\left(T_{\text {age }}\right)$, is continuously buried at a constant convergence velocity $(V)$ along a subduction plane with prescribed dip angle $(\theta)$, to simulate the subduction of an initially flat oceanic lithosphere down to the mantle. The model box is $85 \mathrm{~km} \mathrm{high,}$ and the width of the model is adjusted depending on $\theta$ to ensure a constant grid resolution of $1 \mathrm{~km}$ in all models.

The initial temperature is computed following a half space oceanic geotherm equation (e.g.,

917 Turcotte and Schubert, 2002), expressing the temperature $T$ as a function of depth (z). Such a 918 thermal profile depends on the thermal properties of the rocks (i.e., $k, \rho$ and $C p$ ), on the thermal age $919 T_{\text {age }}$ of the oceanic lithosphere and on the difference between the temperature of the mantle $T_{m}$ and 920 the surface $T_{s}$, fixed at $1350^{\circ} \mathrm{C}$ and $0^{\circ} \mathrm{C}$, respectively. Thermal properties used both for this initial 921 thermal profile and during the simulations are: $k=2 \mathrm{~W} \cdot \mathrm{m}^{-1} \cdot \mathrm{K}^{-1}, \rho=3000 \mathrm{~kg} \cdot \mathrm{m}^{-3}$ and $C p=1000$ J.kg ${ }^{-1} \cdot \mathrm{K}^{-1}$. 


$$
\rho \cdot C_{p} \cdot \frac{\partial T}{\partial t}=\frac{\partial}{\partial x}\left(k \frac{\partial T}{\partial x}\right)+\frac{\partial}{\partial z}\left(k \frac{\partial T}{\partial z}\right)+Q
$$

where $\rho, C p$, and $k$ are the density, the heat capacity and the thermal conductivity, respectively. $Q$, which corresponds to the heat production part (due, for instance, to radiogenic heat production or shear heating), is set to 0 . This point is however discussed below and in the discussion section.

This equation (Eq. 1) is solved by using the implicit finite difference method on the Eulerian grid (e.g., Gerya, 2010). Temperature at the top of the model is fixed at $0^{\circ} \mathrm{C}$, while the left and right sides of the model are subject to insulating boundary conditions (i.e., $\frac{\partial T}{\partial x}=0$ ). The boundary 934 condition at the bottom of the model is that of a constant flux (i.e., $\frac{\partial^{2} T}{\partial z^{2}}=0$ ). The temperature $T$ computed on the nodes is then interpolated on markers and advected through the model by following the imposed velocity field (see Gerya, 2010 and Duprat-Oualid et al., 2013).

\section{Parametric study}

The influence of the convergence velocity $V$, subduction dip angle $\theta$ and initial age of the oceanic lithosphere $T_{\text {age }}$ (controlling the initial thermal profile, Eq. 2) has been tested through a 941 parametric study. For the sake of clarity, we focus the following description on the range of 942 temperatures associated with HT sole formation (for which refined constraints on their P-T 943 conditions of formation also exist; Fig. 3b).

944 Results show that the kinematic parameters $(V, \theta)$ control the time at which the tip of the slab 945 reaches a given temperature (Fig. S2c), while the initial thermal age of the oceanic lithosphere 946 controls the depth where this occurs (Fig. S2b). Considering a velocity of $3 \mathrm{~cm} . \mathrm{yr}^{-1}$ and a dip of 30 $947 \circ$ for the subducting slab $\left(V \cdot \sin (\theta)\right.$ is $\left.1.5 \mathrm{~cm} \cdot \mathrm{yr}^{-1}\right)$, a very low initial $T_{\text {age }}$ is required to reach $700^{\circ} \mathrm{C}$ 948 in less than $\sim 2$ My (Fig. S2b). This is why our reference experiment uses a $T_{\text {age }}$ of 3 Ma. In such a 
configuration, our models predict that the temperature of $\sim 750^{\circ} \mathrm{C}$ will be reached at around $20 \mathrm{~km}$

950 depths (Fig. S2d).

951

952

953

954

955

956

957

958

959

960

961

962

963

964

965

966

967

968

969

970

971

972

973

974

975

\section{Results from modelling}

The initial thermal age, convergence velocity and slab dip are set to $3 \mathrm{Ma}, 3 \mathrm{~cm} . \mathrm{yr}^{-1}$ and $30^{\circ}$ in the reference model, so that the tip of the oceanic crust located on top of the slab reaches $750^{\circ} \mathrm{C}$ and $20 \mathrm{~km}$ depth after $\sim 1.5 \mathrm{My}$ (and $1000^{\circ} \mathrm{C}$ at $\sim 25 \mathrm{~km}$ depth after $1.75 \mathrm{My}$; Fig. S2d). This configuration is the one adopted in Figure 5.

Thermo-kinematic models constrain the evolution of temperature through time along the plate interface for given depths, shown here at 10-20-30-40 km for the reference experiment (Fig. S3a). T-time trajectories of evenly spaced incoming rocks (i.e., at the slab tip and then every $30 \mathrm{~km}$ away, for points A, B, C and D; Fig. S1d) are shown on figure S3b.

The evolution of temperature through time along the plate interface and T-time trajectories (Fig. S3) show that a rock starting to subduct $1 \mathrm{My}$ after subduction initiation (point B; Fig. S4) will be in the temperature range of formation of the HT sole and mafic/ultramafic rheological switch $\left(\sim 750-850^{\circ} \mathrm{C}\right)$ between 2.8 and 3.2 My at 27-32.5 km depth. The depth and duration over which incoming rocks remain in this temperature interval, for a range of realistic upper plate thermal ages and slab dips (Fig. S4), is $25 \pm 7 \mathrm{~km}$ (across a few $\mathrm{km}$ on either side of the thrust) for no more than 0.3-0.4 My.

\section{Influence of shear heating.}

Shear heating $(H s)$ corresponds to the transformation of mechanical energy into heat during deformation and depends on the strain rate and on the viscosity. For a shear zone with thickness $h$, exhibiting a homogeneously distributed shear velocity $V$ and an effective mean viscosity $\eta$, $H_{s}$ can be expressed as (e.g., Duprat-Oualid et al., 2015):

$$
H s=\eta \frac{V^{2}}{h^{2}},
$$


977 strain rate as presented in figure S5. Results show that $H s$ strongly affects the thermal evolution 978 around shear zones, especially for high viscosity values. The temperature conditions for the 979 formation of the metamorphic sole are in this case located at shallower depth than in experiments 980 which do not include shear heating. This results are obtained for constant viscosity and do not 981 account for the T-dependency of viscosity: in nature, however, almost all materials (see Fig. 4b) 982 present a decrease in viscosity with increasing temperature. These simulations therefore provide an 983 estimate of the maximum influence of shear heating, reality being probably between situations 984 shown in figures S2d and S5.

985 The important result is that, even if shear heating highly modifies the thermal field evolution 986 around the shear zone, it does not alter the pattern of the isotherms. Figure S5 indeed shows that 987 whatever the viscosity of the shear zone (and therefore the amount of heat produced by shear 988 heating), the global "S-shape" of the isotherms, and therefore the existence of rheological switches, 989 is always reproduced. Consequently, although shear heating can impact the depth of metamorphic 990 sole formation, it does not affect the processes related to plate interface rheological switches that we 991 propose in this study. 


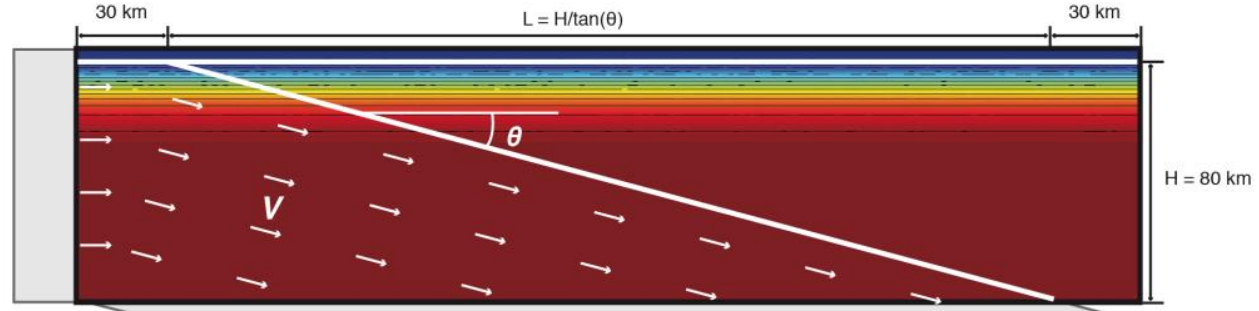

$\underset{1350}{\mathrm{~T}}\left[{ }^{\circ} \mathrm{C}\right]$
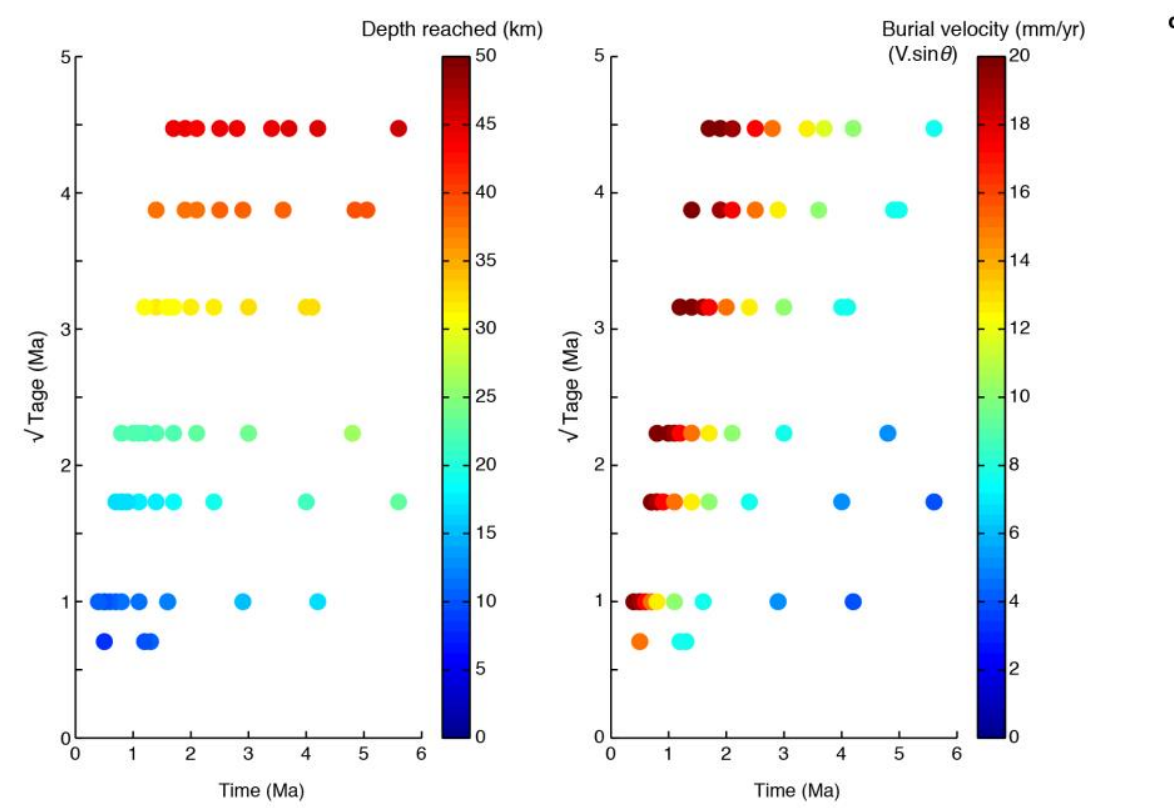

Figure S2. Thermo kinematic modelling of the temperature field associated with slab penetration into the mantle during subduction infancy; (a) Set-up of the numerical model. The initial temperature field is flat and depends on the thermal age of the oceanic lithosphere $\left(T_{\text {age }}\right) . V$ corresponds to the convergence velocity; (b) and (c): Variations, as a function of time and initial oceanic $T_{\text {age }}$, of the depth (left panel) and burial velocity $(V \cdot \sin \theta$; right panel) required for the tip of the slab to reach the temperature of $700^{\circ} \mathrm{C}$. Depths of metamorphic sole formation are chiefly controlled by the initial $T_{\text {age }}$ of the oceanic lithosphere (left panel), while kinematic parameters control the time at which this happens (right panel); (d) Thermal structure of the reference model after 1.75, 2.75 and 3.75 Myrs, which was used in figure 5. 

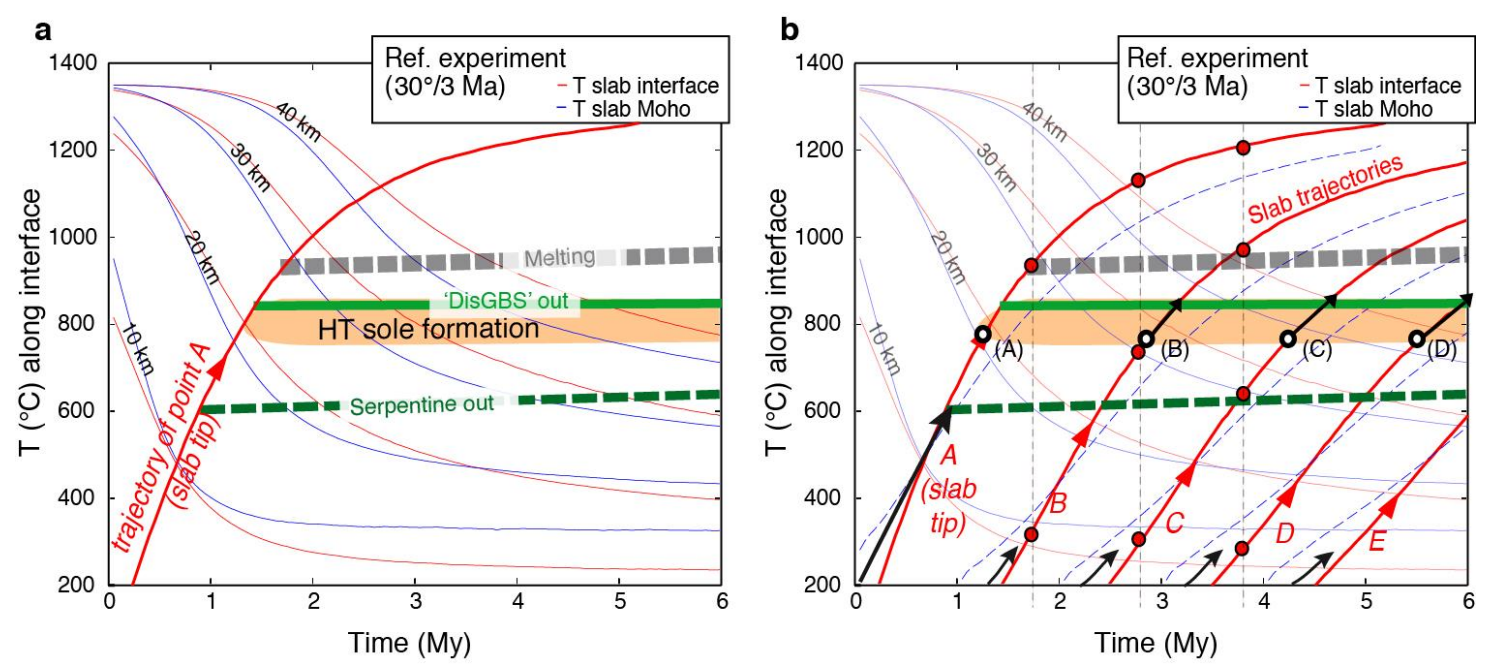

Figure S3. Thermal modelling of slab penetration during subduction infancy. (a) Evolution of slab temperatures along crust-mantle boundaries at depths of 10-20-30-40 km (thin curves). Red line: Ttime trajectory of the surface temperature of point A (tip of the slab). Orange overlay: T range of HT sole formation. Incipient melting of basaltic crust is given for an average value between wet and dry MORB (Kessel et al., 2005). See text for deformation mechanisms (disGBS: dislocationaccomodated grain boundary sliding; Linckens et al., 2011a; Hirth and Kohlstedt, 2015); (b) Thick red lines give T-time trajectories for evenly spaced points along the top of the slab (A: slab tip; points A to E are spaced every $30 \mathrm{~km}$; see Fig. S2d). Temperatures along the slab Moho are shown with dashed blue lines. Open black circles indicate when a given point enters the conditions of metamorphic sole formation (black arrows outline approximate duration under these conditions). 


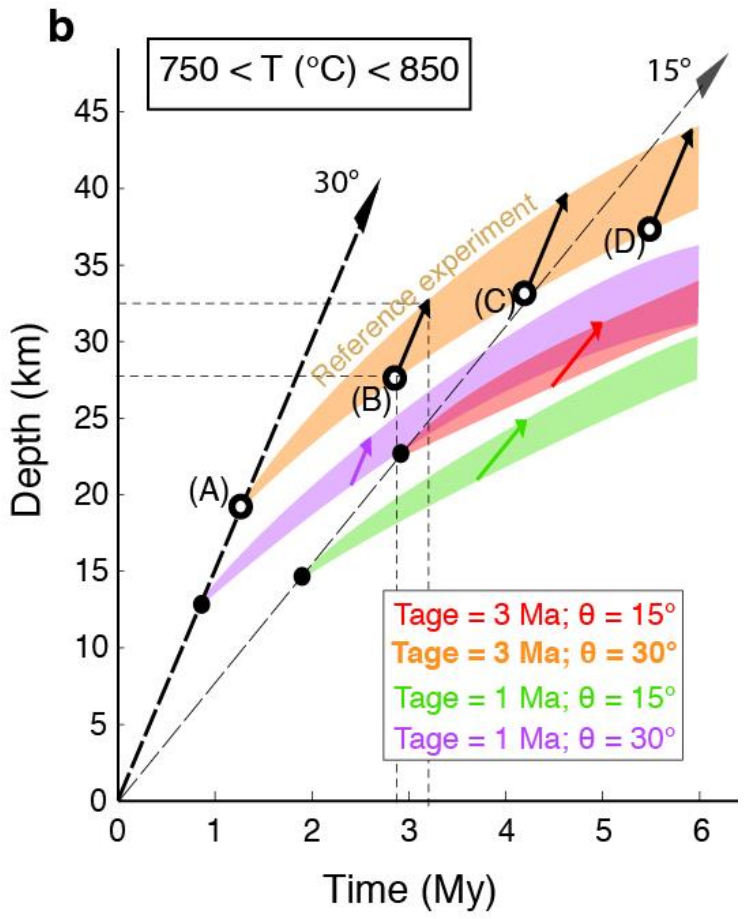

Figure S4. Duration and depth over which incoming rocks remain between 750 and $850^{\circ} \mathrm{C}$, during the first rheological switch and HT sole formation (Fig. 4d), depending on upper plate thermal age and slab dip. For the reference experiment, incoming crustal rocks may cross the temperature range of HT sole formation $\left(\sim 750-850^{\circ} \mathrm{C}\right)$ at depths of $\sim 25-35 \mathrm{~km}$ : accretion of individual slices may last on the order of 0.3-0.4 My, while 1-3 My would be required to fully accrete the first incoming 100 $\mathrm{km}$ of crust on the top of the slab (A to C or D; see text, section 5.2.i for further discussion). 
1044

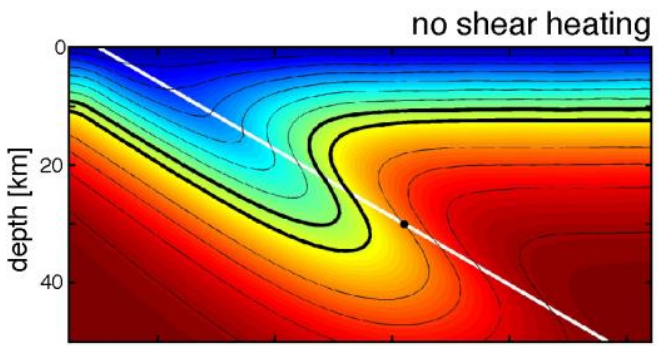

with shear heating: $\eta=1 \mathrm{e} 20.5 \mathrm{~Pa} . \mathrm{s}$

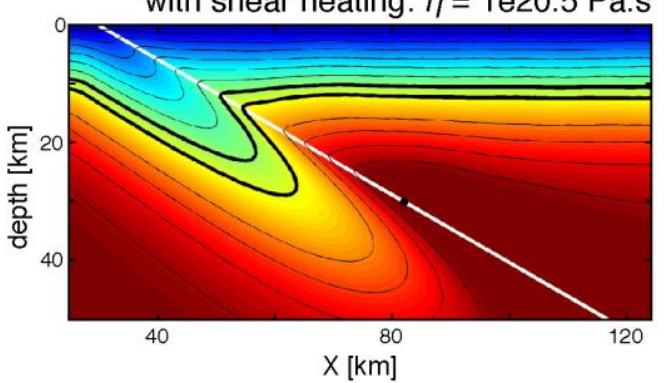

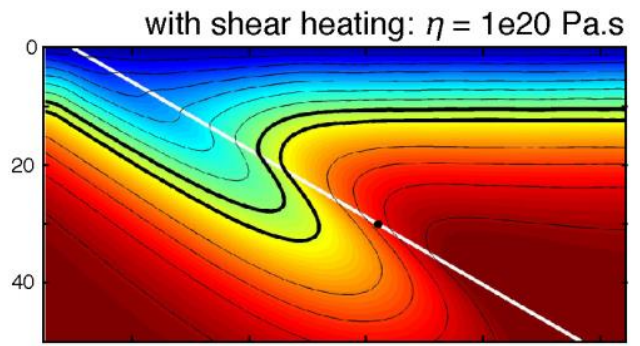

with shear heating: $\eta=1 \mathrm{e} 21 \mathrm{~Pa} . \mathrm{s}$

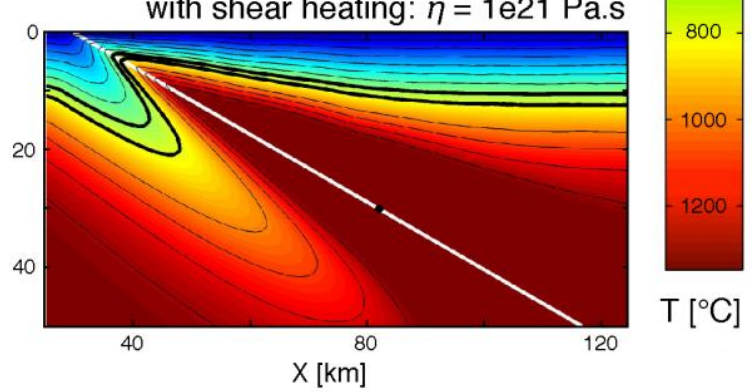

Figure S5. Influence of shear heating on the thermal evolution of the subduction zones. Plots are provided here after $2 \mathrm{My}$ (see details in the supplementary material section 4 above). The top-left panel corresponds to the thermal field obtained for the reference model, with no shear heating. In the 3 others panels, heat production by shear heating is implemented assuming a shear zone thickness of $1 \mathrm{~km}$ and a constant viscosity $\left(10^{20}, 10^{20.5}\right.$ and $10^{21}$ Pa.s, respectively). As the viscosity of rocks is strongly temperature dependent (Fig. 4b), these simulations are not fully consistent but nevertheless useful since the viscosity values considered here lie in the range inferred from natural data $\left(10^{20}\right.$ Pa.s: Tasaka et al., 2013; $10^{21}$ Pa.s: Linckens et al., 2011). Black curves correspond to the 700 and $800^{\circ} \mathrm{C}$ isotherms. The black dot is located at a depth of $30 \mathrm{~km}$ for reference. 


\section{Additional references for this Supplementary Material}

Duprat-Oualid, S., Yamato, P. \& Pitra, P. 2013. Major role of shear heating in intracontinental 1066 inverted metamorphism: Inference from a thermo-kinematic parametric study. Tectonophysics $608,812-831$.

1069 Duprat-Oualid, S., Yamato, P., \& Schmalholz S.M., 2015. A dimensional analysis to quantify the thermal budget around lithospheric-scale shear zones, Terra Nova, 27, 163-168.

1072 Gerya, T,V., 2010. Introduction to Numerical Geodynamic Modelling, Cambridge Univ. Press.

1074 Turcotte, D.L., Schubert, G., 2002. Geodynamics, 2nd edition. Wiley. 1075 


\section{References for Table 1}

1078

1079 Al-Ryami, K., Robertson, A., Dixon, J. \& Xenophontos, C. 2002. Origin and emplacement of the 1080 Late Cretaceous Baer-Bassit ophiolite and its metamorphic sole in NW Syria. Lithos. 65, 225-

Bucher, M. 1980. Mineral equilibria in metagabbros: Evidence for polymetamorphic evolution of the Asimah windows, Northern Oman Mountains, United Arab Emirates, in Ophiolite Genesis and Evolution of Oceanic Lithosphere. Peters, T., Nicolas, A. \& Coleman, R. G. Eds., Kluwer (Dordrecht) 543-571. chemistry. J. Asian Earth Sci. 26, 461-476.

Çelik, O. F. \& Delaloye, M. F. 2006. Characteristics of ophiolite-related metamorphic rocks in the Beysehir ophiolitic mélange (Central Taurides, Turkey), deduced from whole rock and mineral

Clague, D., Rubin, J. \& Brackett, R. 1981. The age and origin of the garnet amphibole underlying the Thetford-Mines ophiolite. Can. J. Earth Sci. 18, 469-486.

Cluzel, D., Jourdan, F., Meffre, S., Maurizot, P. \& Lesimple, S. 2012. The metamorphic sole of New Caledonia ophiolite: 40Ar/39Ar, U-Pb, and geochemical evidence for subduction inception at a spreading ridge. Tectonics. 31, TC3016.

Cowan, R. J., Searle, M. P. \& Waters, D. J. 2014. Structure of the metamorphic sole to the Oman Ophiolite, Sumeini Window and Wadi Tayyin: implications for ophiolite obduction processes, Geol. Soc., London Sp. Pub. 392, 155-175.

de Capitani, C. \& Brown, T.H. 1987. The computation of chemical equilibrium in complex systems containing non-ideal solutions. Geoch. Cosmochim. Acta 51, 2639-2652.

Dilek, Y. \& Whitney, D. L. 1997. Counterclokwise P-T-t trajectory from the metamorphic sole of a Neo-Tethyan ophiolite (Turkey). Tectonophysics. 280, 295-310.

1102 metamorphic sole, Eastern Desert, Egypt. J. Metamorph. Geol. 18, 639-651. 
1103 Encarnacion, J. P., Essene, E. J., Mukasa, S. B. \& Hall, C. H. 1995. High-pressure and -temperature 1104 subophiolitic kyanite-garnet amphibolites generated during initiation of mid-tertiary 1105 subduction, Palawan, Philippines. J. Petrol. 36, 1481-1503.

1106 Farahat, E. S. 2011. Geotectonic significance of Neoproterozoic amphibolites from the Central 1107 Eastern Desert of Egypt: A possible dismembered sub-ophiolitic metamorphic sole. Lithos. 125, $1108 \quad 781-794$.

1109 Gaggero, L., Marroni, M., Pandolfi, L., \& Buzzi, L. 2009. Modeling the oceanic lithosphere 1110 obduction: Constraints from the metamorphic sole of Mirdita ophiolites (Northern Albania). $1111 \quad$ Ofioliti. 34, 17-42.

1112 Gartzos, E., Dietrich, V. J., Migiros, G., Serelis, K., Lymperopoulou, T. 2009. The origin of 1113 amphibolites from metamorphic soles beneath the ultramafic ophiolites in Evia and Lesvos 1114 (Greece) and their geotectonic implication. Lithos. 108, 224-242.

1115 Ghent, E. \& Stout, M. 1981. Metamorphism at the base of the Samail Ophiolite, Southeastern Oman 1116 Mountains. J. Geophys Res. 86, 2557-2571.

1117 Gnos, E. \& Kurz, D. 1994. Sapphirine-quartz and sapphirine-corundum assemblages in 1118 metamorphic rocks associated with the Semail Ophiolite (United Arab Emirates). Contrib. $1119 \quad$ Mineral Petrol. 166, 398-410.

1120 Gnos, E. 1998. Peak Metamorphic Conditions of Garnet Amphibolites Beneath the Semail 1121 Ophiolite: Implications for an Inverted Pressure Gradient. Int. Geol. Rev. 40, 281-304.

1122 Green, E., Holland, T. J. B. \& Powell, R. 2007. An order-disorder model for omphacitic pyroxenes 1123 in the system jadeite-diopside-hedenbergite-acmite, with applications to eclogitic rocks. Am. $1124 \quad$ Mineral. 92, 1181-1189.

1125 Guilmette, C. et al. 2012. Discovery of a dismembered metamorphic sole in the Saga ophiolitic 1126 mélange, South Tibet: Assessing an Early Cretaceous disruption of the Neo-Tethyan supra1127 subduction zone and consequences on basin closing. Gondwana Res. 22, 398-414.

1128 Hacker, B. R. 1994. Rapid Emplacement of Young Oceanic Lithosphere: Argon Geochronology. $1129 \quad$ Science 265, 1563-1565. 
1130

1131

1132

1133

1134

1135

1136

1137

1138

1139

1140

1141

1142

1143

1144

1145

1146

1147

1148

1149

1150

1151

1152

1153

1154

1155

1156

Hacker, B. R. \& Mosenfelder, J. L. 1996. Metamorphism and deformation along the emplacement thrust of the Samail ophiolite, Oman. Earth Planet. Sc. Lett. 144, 435-451.

Hacker, B. R., Mosenfelder, J. L. \& Gnos, E. 1996. Rapid emplacement of the Oman ophiolite: Thermal and geochronologic constraints. Tectonics. 15, 1230-1247.

Hacker, B. R. \& Gnos, E. 1997. The conundrum of samail: explaining the metamorphic history. Tectonophysics 279, 215-226.

Harris, R. A. 1998. Origin and tectonic evolution of the metamorphic sole beneath the Brooks Range ophiolite, Alaska. Geol. Soc. Am. Spec. Paper. 324, 293-312.

Hassig, M. et al. 2013. New structural and petrological data on the Amasia ophiolites (NW SevanAkera suture zone, Lesser Caucasus): Insights for a large-scale obduction in Armenia and NE Turkey. Tectonophysics 588, 135-153.

Hassig, M., Rolland, Y. Sosson, M., Galoyan, G., Müller, C. et al. 2015. European Geosciences Union (EGU) General Assembly, April 27th-May 2nd, Vienna.

Holland, T. J. B. \& Blundy, J. 1994. Non-ideal interactions in calcic amphiboles and their bearing on amphibole-plagioclase thermometry. Contrib. Mineral Petrol. 116, 433-447.

Holland, T. J. B., Baker, J. \& Powell, R. 1998. Mixing properties and activity-composition relationships of chlorites in the system MgO-FeO-A12O3-SiO2-H2O. Eur. J. Mineral. 10, 395406.

Jamieson, R. A. 1981. Metamorphism during ophiolite emplacement - the petrology of the St Anthony Complex, J. Petrol. 22, 397-443.

Jamieson, R. A. 1986. P-T paths from high temperature shear zones beneath ophiolites. J. Metam. Geol 4, 3-22.

Lazaro, C. et al. 2013. First description of a metamorphic sole related to ophiolite obduction in the northern Caribbean: Geochemistry and petrology of the Güira de Jauco Amphibolite complex (eastern Cuba) and tectonic implications. Lithos 179, 193-210.

Lus, W. Y., McDougall, I. \& Davies, H. L. 2004. Age of the metamorphic sole of the Papuan Ultramafic Belt ophiolite, Papua New Guinea. Tectonophysics 392, 85-101. 
Malo, M. Ruffet, G., Pincivy, A. \& Tremblay, A. 2008. A 40Ar/39Ar study of oceanic and continental deformation processes during an oblique collision: Taconian orogeny in the Quebec reentrant of the Canadian Appalachians. Tectonics 27, TC4001.

McCaig, A. M. 1983. P-T conditions during emplacement of the Bay of Islands ophiolite complex. Earth Planet. Sci. Lett. 63, 459-473.

Meffre, S. et al. 2012. Basalts erupted along the Tongan fore arc during subduction initiation: Evidence from geochronology of dredged rocks from the Tonga fore arc and trench. Geochem. Geophy. Geosyst. 13, Q12003.

Newton, R. C., Charlu, T. V. \& Kleppa, O. J. 1980. Thermochemistry of the high structural state plagioclases, Geochim. Cosmochim. Acta 44, 933-941.

O'Beirne-Ryan, A. M., Jamieson, R. A. \& Gagnon, Y. D. 1990. Petrology of garnet-clinopyroxene amphibolites from Mont Albert, Gaspé, Quebec. Can. J. Earth Sci. 27, 72-86.

Okay, A. I., Harris, N. B. W. \& Kelley, S. P. 1998. Exhumation of blueschists along a Tethyan suture in northwest Turkey. Tectonophysics. 285, 275-299.

Önen, A. P. \& Hall, R. 1993. Ophiolites and related metamorphic rocks from the Kütahya region, north-west Turkey. Geo. J. 28, 399-412.

Önen, A. P. 2003. Neotethyan ophiolitic rocks of the anatolides of NW Turkey and comparison with Tauride ophiolites. J. Geol. Soc. 160, 947-962.

Pamic, J., Tomljenovic, B. \& Balen, D. 2002. Geodynamic and petrogenetic evolution of Alpine ophiolites from the central and NW Dinarides: an overview. Lithos. 65, 17-42.

Parkinson, C. 1998. Emplacement of the East Sulawesi Ophiolite: evidence from subophiolite metamorphic rocks. J. As. Earth Sci. 16, 13-28.

Parlak, O. \& Delaloye, M. F. 1999. Precise 40Ar/39Ar from the metamorphic sole of the Mersin ophiolite (southern Turkey). Tectonophysics. 301, 145-158.

Parlak, O., Bozkurt, E. \& Delaloye, M. F. 1996. The Obduction direction of the Mersin ophiolite: structural evidence from subophiolitic metamorphics in the Central Tauride Belt, Southern Turkey. Int. Geol. Rev. 38, 778-786. 
Plunder, A., Agard, P., Chopin, C., Pourteau, A., \& Okay, A. I. 2015. Accretion, underplating and exhumation along a subduction interface: From subduction initiation to continental subduction (Tavşanlı zone, W. Turkey). Lithos 226, 233-254.

Powell, R. \& Holland, T. J. B. 1999. Relating formulations of the thermodynamics of mineral solid solutions: Activity modeling of pyroxenes, amphiboles, and micas, Am. Mineral. 84, 1-14.

Saccani, E. \& Photiades, A. 2004. Mid-ocean ridge and supra-subduction affinities in the Pindos ophiolites (Greece): implications for magma genesis in a forearc setting. Lithos. 73, 229-253.

Savic, G. 1988. Ph-D thesis, University of Houston, Texas.

Searle, M. P. \& Malpas, J. 1980. Petrochemistry and origin of sub-ophiolitic metamorphic and related rocks in the Oman Mountains. J. Geol. Soc. 139, 235-248.

Searle, M. P. \& Cox, J. 2002. Subduction zone metamorphism during formation and emplacement of the Semail ophiolite in the Oman Mountains. Geol. Mag. 139, 241-255.

Spear, F. S. 1981. An experimental study of hornblende stability and compositional variability in amphibolite. Am. J. Sci. 281, 697-734.

Trzcienski, W. E. 1988. Retrograde eclogite from Mont Albert, Gaspé, Quebec. Can. J. Earth Sci. $25,30-37$.

Warren, C. J., Parish, R. R., Searle, M. P. \& Waters, D. J. 2003. Dating the subduction of the Arabian continental margin beneath the Semail ophiolite, Oman. Geology. 31, 889-892. 


\section{References for Table 2}

Bussod, G.Y., Katsura, T., Rubie, D.C. 1993. The large volume multi-anvil press as a high P-T deformation apparatus. Pure Applied Geophys., 141, 579-599.

1210 Chopra, P.N., Paterson,M.S., 1981. The experimental deformation of dunite. Tectonophysics 78, $1211 \quad 453-473$.

1212 Chopra, P.N., Paterson, M.S., 1984. The role of water in the deformation of dunite. J. Geophys. Res. 1213 $89,7861-7876$.

1214 Evans, B. and Kohlstedt, D. L. 1995. Rheology of Rocks. In: Rock Physics \& Phase Relations: A Handbook of Physical Constants (ed T. J. Ahrens), American Geophysical Union, Washington, D. C., 148-165.

Faul, U. H., Jackson, I. 2007. Diffusion creep of dry, melt-free olivine, J. Geophys. Res., 112, B04204, doi:10.1029/2006JB004586.

Hacker, B.R. and Christie, J.M. 1990. Brittle/ductile and plastic/cataclastic transitions in experimentally deformed and metamorphosed amphibolite. Geophysical Monograph 56, 127 -

Hilairet, N., Reynard, B., Wang, Y., Daniel, I., Merkel, S., Nishiyama, N., Petitgirard, S. 2007. High-pressure creep of serpentine, interseismic deformation and initiation of subduction. Science. 318, 1910-1913.

Hirth, G., Kohlstedt, D.L., 1996. Water in the oceanic upper mantle-implications for rheology, melt extraction and the evolution of the lithosphere. Earth Planet. Sci. Letters 144, 93-108.

Hirth, G., Kohlstedt, D.L., 2003. Rheology of the upper mantle and the mantle wedge: a view from the experimentalists. In: Inside the Sub-duction Factory (Ed. Eiler, J.), Geophys. Monogr. 138, American Geophysical Union, Washington, D.C., 83-105.

Karato, S.-I., Paterson, M.S., Fitzgerald, J.D., 1986. Rheology of synthetic olivine ag-gregates; influence of grain size and water. J. Geophys. Res.91 (8), 8151-8176.

1233 Karato, S., Rubie, D.C., 1997. Toward experimental study of plastic deformation under deep mantle 
conditions: a new multianvil sample assembly for deformation experiments under high pressures and temperatures. J. Geophys. Res. 102, 20111-20122.

1236 Karato, S., Jung, H., 2003. Effects of pressure on high-temperature dislocation creep in olivine. Phil. 1237 Mag. 83.

1238 Kawazoe, T., Karato, S., Otsuka, K., Jing, Z.,Mookherjee, M., 2009. Shear deformation of dry polycrystalline olivine under deep upper mantle conditions using a rotational Drickamer apparatus (RDA). Phys. Earth Planet. Int. 174, 128-137.

1241 Kirby, S. H., Kronenberg, A. K. 1987. Rheology of the lithosphere: Selected topics, Rev. Geophys. 1242 $25,1219-1244$.

1243 Kronenberg, A. K., Kirby, S. H. \& Pinkston, J. C. 1990. Basal slip and mechanical anisotropy of 1244 biotite. J. Geophys. Res. 95, 19257-19278.

1245 Li, L., Weidner, D., Ratteron, P., Chen, J., Vaughan, M., Mei, S., Durham, B. 2006. Deformation of 1246 olivine at mantle pressure using the D-DIA. Eur. J. Min. 18, 7-19.

1247 Mackwell, S.J., Zimmerman, M.E., Kohlstedt, D.1., 1998. High-temperature deformation of dry 1248 diabase with application to tectonics on Venus. J. Geophys. Res. 103, 975-984.

McDonnell, R.D., Peach, C.J., Spiers, C.J. 1999. Flow behavior of fine-grained synthetic dunite in the presence of $0.5 \mathrm{wt} \%$ H2O. J. Geophys. Res. 104, 17823-17845.

Mei, S., Kohlstedt, D.L., 2000. Influence of water on plastic deformation of olivine aggregates 2. Dislocation creep regime. J. Geophys. Res.105, 21471-21481.

1253 Ranalli, G., Murphy, D.C., 1987. Rheological stratification of the lithosphere, Tectonophysics 132, $1254 \quad 281-295$.

1255 Shea, W. T. \& Kronenberg, A. K. 1992. Rheology and deformation mechanisms of an isotropic 1256 Mica Schist, J. Geophys. Res. 97, 15201-15237.

1257 Shelton, G. \& Tullis, J. A. 1981. Experimental flow laws for crustal rocks, Trans. Am. Geophys. Un. $1258 \quad 62,396$.

1259 van Hunen, J., van den Berg, A.P. 2008. Plate tectonics on the early Earth: Limitations imposed by 1260 strength and buoyancy of subducted lithosphere. Lithos, 103, 217-235. 
1261 Wilks, K.R., Carter, N.L., 1990. Rheology of some continental lower crustal rocks. Tectonophysics $1262 \quad 182,57-77$.

1263

1264

1265 
